\title{
Surface Modification of Magnetic Iron Oxide Nanoparticles
}

\author{
Nan Zhu ${ }^{1}$, Haining Ji ${ }^{1, *}$, Peng Yu ${ }^{2}{ }^{\oplus}$, Jiaqi Niu ${ }^{1}$, M. U. Farooq ${ }^{2}{ }^{\oplus}$, M. Waseem Akram ${ }^{2}{ }^{\circledR}$, \\ I. O. Udego ${ }^{2}$, Handong $\mathrm{Li}^{1}$ and Xiaobin Niu ${ }^{1}$ \\ 1 School of Materials and Energy, University of Electronic Science and Technology of China, \\ Chengdu 610054, China; 18651927042@163.com (N.Z.); jiaqi_niu@163.com (J.N.); hdli@uestc.edu.cn (H.L.); \\ xbniu@uestc.edu.cn (X.N.) \\ 2 Institute of Fundamental and Frontier Science, University of Electronic Science and Technology, \\ Chengdu 610054, China; Azarisyu@gmail.com (P.Y.); ufbajwa@yahoo.com (M.U.F.); \\ waseem.physicist@gmail.com (M.W.A.); Israel.udego@yahoo.com (I.O.U.) \\ * Correspondence: hainingji@163.com; Tel.: +86-185-8375-1368
}

Received: 28 August 2018; Accepted: 5 October 2018; Published: 9 October 2018

\begin{abstract}
Functionalized iron oxide nanoparticles (IONPs) are of great interest due to wide range applications, especially in nanomedicine. However, they face challenges preventing their further applications such as rapid agglomeration, oxidation, etc. Appropriate surface modification of IONPs can conquer these barriers with improved physicochemical properties. This review summarizes recent advances in the surface modification of IONPs with small organic molecules, polymers and inorganic materials. The preparation methods, mechanisms and applications of surface-modified IONPs with different materials are discussed. Finally, the technical barriers of IONPs and their limitations in practical applications are pointed out, and the development trends and prospects are discussed.
\end{abstract}

Keywords: magnetic nanoparticles; nanomedicine; iron oxide nanoparticles; surface modification

\section{Introduction}

Recently, magnetic nanoparticles is an emerging field of study and has gained much attention among researchers due to their widespread applications in various fields including catalysis [1], data storage [2], environmental remediation [3], magnetic fluids [4], electronic communication [5], and biomedicine [6] etc. Among different types of magnetic nanoparticles (MNPs), iron oxide nanoparticles (IONPs) are the most popular and widely used in the field of biomedicine due to their ease of surface modification, synthesis, and low toxicity [7]. Current studies and literature have confirmed that magnetic IONPs are frequently used in the treatment of hyperthermia [8-10] or as drug carriers in cancer treatment [11-13], magnetic resonance imaging (MRI) agents [14-16], bioseparation [17-19], gene delivery [20-22], biosensors [23-25], protein purification [26-28], immunoassays [29-31] and cell labeling [32-34].

However, IONPs suffer from two major issues such as rapid agglomeration, oxidation into the physiological environment of the tumors due to large surface area, chemical reactivity and high surface energy, thus resulting in a loss of magnetism [35]. Therefore, appropriate surface modification of IONPs is required to make them biocompatible. The coating method is the most common surface modification approach to conjugate the organic or inorganic materials onto the surface of IONPs. This method not only prevents the oxidation and agglomeration of IONPs, but also provides the possibility for further functionalization [36]. Functionalization of magnetic IONPs can improve their physicochemical properties, making them ideal candidates for the field of catalysis and biomedicine. 
Different characteristics such as size, shape, morphology and dispersability of the IONPs can affect their application in biomedicine $[37,38]$. Therefore, researchers are focusing on synthesizing MNPs by adopting different routes to control their size, shape and morphology with adjustable and desirable properties. So far, a number of synthesis routes such as co-precipitation [39], hydrothermal [40], thermal decomposition [41], microemulsion [42], electrochemical deposition [43], laser pyrolysis [44], solvothermal methods [45], sonochemical methods [46], chemical vapor deposition [47], the microwave assisted method [48], and aerosol pyrolysis [49] have been reported to prepare the magnetic IONPs. The advantages and disadvantages of some methods are listed in Table 1.

Table 1. Principal preparation methods of iron oxide nanoparticles (IONPs).

\begin{tabular}{ccc}
\hline Method & Advantages & Disadvantages \\
\hline Co-precipitation method & Simple and efficient & $\begin{array}{c}\text { Size distribution, poor crystallinity } \\
\text { and aggregation }\end{array}$ \\
\hline Hydrothermal reactions & $\begin{array}{c}\text { Easy to control particle size } \\
\text { and shape }\end{array}$ & $\begin{array}{c}\text { Long reaction time, high reaction } \\
\text { temperature, high pressure }\end{array}$ \\
\hline Thermal decomposition & $\begin{array}{c}\text { Good control of size and } \\
\text { shapes, high yield }\end{array}$ & High reaction temperature \\
\hline Microemulsion method & $\begin{array}{c}\text { Control of particle size, } \\
\text { highly homogeneous }\end{array}$ & $\begin{array}{c}\text { Poor yield, large amounts of solvent } \\
\text { required and time consuming }\end{array}$ \\
\hline Sol-gel reactions & $\begin{array}{c}\text { Precise control of size } \\
\text { and structure }\end{array}$ & $\begin{array}{c}\text { Relatively expensive, long reaction time } \\
\text { Aerosol/vapor phase method }\end{array}$ \\
\hline Electrochemical method & Easy control of size & Extremely high temperatures \\
\hline
\end{tabular}

In this review, first we briefly describe the factors influencing why surface modification of MNPs is essentially required, and then introduce the structures of magnetic iron oxide nanocomposites. The materials used in surface modification are categorized as organic materials and inorganic materials. Organic material molecules are composed of small molecules and polymers while inorganic materials include silica, carbon, metals and metal oxides/sulfides. In next section, we summarize the IONPs' surface coating mechanisms as well as the progress made in recent years, and highlight their applications in various fields.

\section{Surface Modification of Magnetic Iron Oxide Nanoparticles (IONPs) and Applications}

There are four main purposes of surface modification of NPs: (1) to improve or change the dispersion of MNPs; (2) to improve the surface activity of MNPs; (3) to enhance the physicochemical and mechanical properties; and (4) to improve the bicompatibility of MNPs. There are mainly four magnetic iron oxide nanocomposites (Figure 1) [50]. 


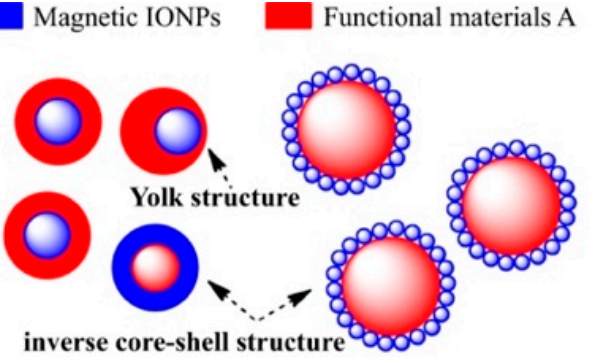

Core-Shell Structure
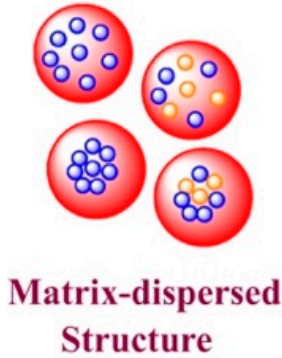

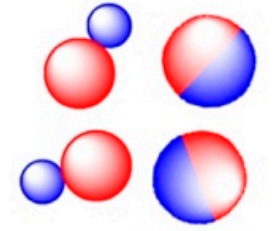

Janus Structure
Functional materials B

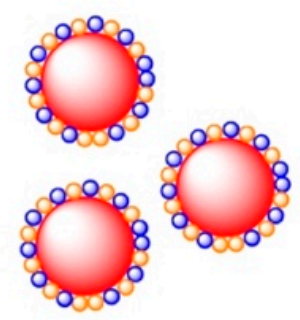

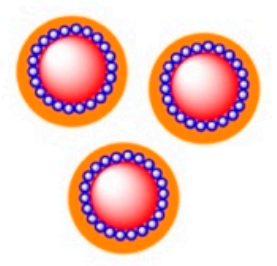

\section{Shell-Core-Shell Structure}

Figure 1. Typical morphologies of magnetic composite nanomaterials. Reproduced with permission from [50]. Copyright Institute of Physics, 2015.

\subsection{Surface Coating with Inorganic Materials}

\subsubsection{Silica}

Silica is the most common and widely used agent for surface modification of IONPs [51-55]. Silica coating has following advantages: low agglomeration, enhancing the stability and reducing the cytotoxic effects of MNPs. Therefore, it has demonstrated good biocompatibility, hydrophilicity and stability [56]. Recently, researchers have described the procedure to control the size and thickness of the silica coated NPs [57]. Generally, there are four main approaches to prepare $\mathrm{IONP}_{\mathrm{NSiO}}$ (Table 2) [50].

Table 2. Summary of synthesis methods for silica-coated IONPs.

\begin{tabular}{ccc}
\hline Synthesis Methods & Advantages & Disadvantages \\
\hline Stöber method & $\begin{array}{c}\text { Controllable silica shell and } \\
\text { uniform size, high crystallinity }\end{array}$ & $\begin{array}{c}\text { Lack of understanding of its } \\
\text { kinetics and mechanism }\end{array}$ \\
\hline Microemulsion & $\begin{array}{c}\text { Control of the particle size, } \\
\text { high homogeneous }\end{array}$ & $\begin{array}{c}\text { Poor yield, large amounts of } \\
\text { solvent required and time } \\
\text { consuming }\end{array}$ \\
\hline $\begin{array}{c}\text { Methods based on sodium } \\
\text { silicate solution }\end{array}$ & Control of crystallinity and surface area & Complex experimental conditions \\
\hline
\end{tabular}

The Stöber method is the most common approach to synthesize $\mathrm{IONP}_{\mathrm{S}} \mathrm{SiO}_{2}$, in which the IONPs are uniformly dispersed in ethanol solution, followed by the addition of tetraethoxysilane (TEOS), then finally the aqueous ammonia solution is admixed to the mixed solution [50,58]. As a basic catalyst, ammonia can not only control the particle size, but also inhibit hydrolysis to form particles with regular morphology. Zhao Li et al. found that the size of silica particles increases with the concentration of ammonia, water, and TEOS in the reaction solution. At the same time, she found that an increase in the reaction temperature accelerated the ripening of the silica particles, causing the particle size to increase slightly [59]. This method can be applied to coat a $\mathrm{SiO}_{2}$ layer directly onto the surface of $\mathrm{Fe}_{3} \mathrm{O}_{4}$. Malvindi et al. studied the toxicity of silica-coated IONPs in a vitro model. 
They used the A549 and HeLa lines and incubated cells with surface-modified $\mathrm{Fe}_{3} \mathrm{O}_{4} @ \mathrm{SiO}_{2}$ as well as bare NPs. They reported that the naked NPs show higher toxicity due to their stronger in situ degradation [60]. Uribe Madrid et al. demonstrated the synthesis of $\mathrm{Fe}_{3} \mathrm{O}_{4} @ \mathrm{mSiO}_{2}$ core-shell structures with high specific surface area and different mesoporous silica $\left(\mathrm{mSiO}_{2}\right)$ shell thickness. This composite nanoparticle synthesized via the modified Stöber method shows excellent drug release performance and it is ideal for targeted drug delivery in vivo [61].

The second method is the microemulsion method, which can be divided into two different types, namely water-in-oil (W/O, micelles) and oil-in-water $(\mathrm{O} / \mathrm{W}$, reversed micelles). Sillca-coated IONPs with high crystallinity can be synthesized by the microemulsion process, which comprises water, oil and surfactant [62]. Du et al. synthesized a silica-encapsulated $\mathrm{Fe}_{3} \mathrm{O}_{4}$ core-shell structure by the microemulsion approach and further functionalized with an antiseptic agent cetyl trimethylammonium bromide (CTAB). Their results have shown that the core size of $\mathrm{Fe}_{3} \mathrm{O}_{4} \mathrm{NPs}$ depends on the water/surfactant molar ratio of the microemulsion system [63]. Yang et al. developed an oil-water two-phase layered coating strategy for the preparation of monodisperse dendritic mesoporous silica-encapsulated magnetic nanospheres with pore size of approximately 5.7 to $10.3 \mathrm{~nm}$ and shell thickness of 40 to $100 \mathrm{~nm}$ [64]. Some researchers have put forward their own views on the mechanism of silica coating in reverse microemulsion systems. Ding et al. summarized these viewpoints and found that it is generally accepted that there is a ligand exchange. They systematically studied the factors affecting the core size and shell thickness of $\mathrm{Fe}_{3} \mathrm{O}_{4} @ \mathrm{SiO}_{2} \mathrm{NPs}$. They found that shell thickness increased with an increasing amount of ammonia and TEOS. Meanwhile, the small aqueous domain is suitable for ultrathin silica shell, while the large aqueous domain is essential for a thicker shell. Single-core $\mathrm{Fe}_{3} \mathrm{O}_{4} @ \mathrm{SiO}_{2} \mathrm{NPs}$ with different shell thicknesses are shown in Figure 2 and the surface coating mechanism is depicted in Figure 3 [65]. The microwave-assisted method can also be used to assist in the synthesis of $\mathrm{Fe}_{3} \mathrm{O}_{4} @ \mathrm{SiO}_{2} \mathrm{NPs}$. Lu et al. prepared $\mathrm{Fe}_{3} \mathrm{O}_{4} @ \mathrm{SiO}_{2} \mathrm{NPs}$ with a very thin $\mathrm{SiO}_{2}$ shell $(2.5 \mathrm{~nm})$ by a novel microwave-assisted reverse microemulsion method [66]. The microemulsion method has the advantage of controlling the shape, size distributions and shell thickness. However, the poor yield and demand of large amounts of solvent are the major drawbacks of this method. The separation of NPs from surfactants is often time consuming and requires much effort [62].

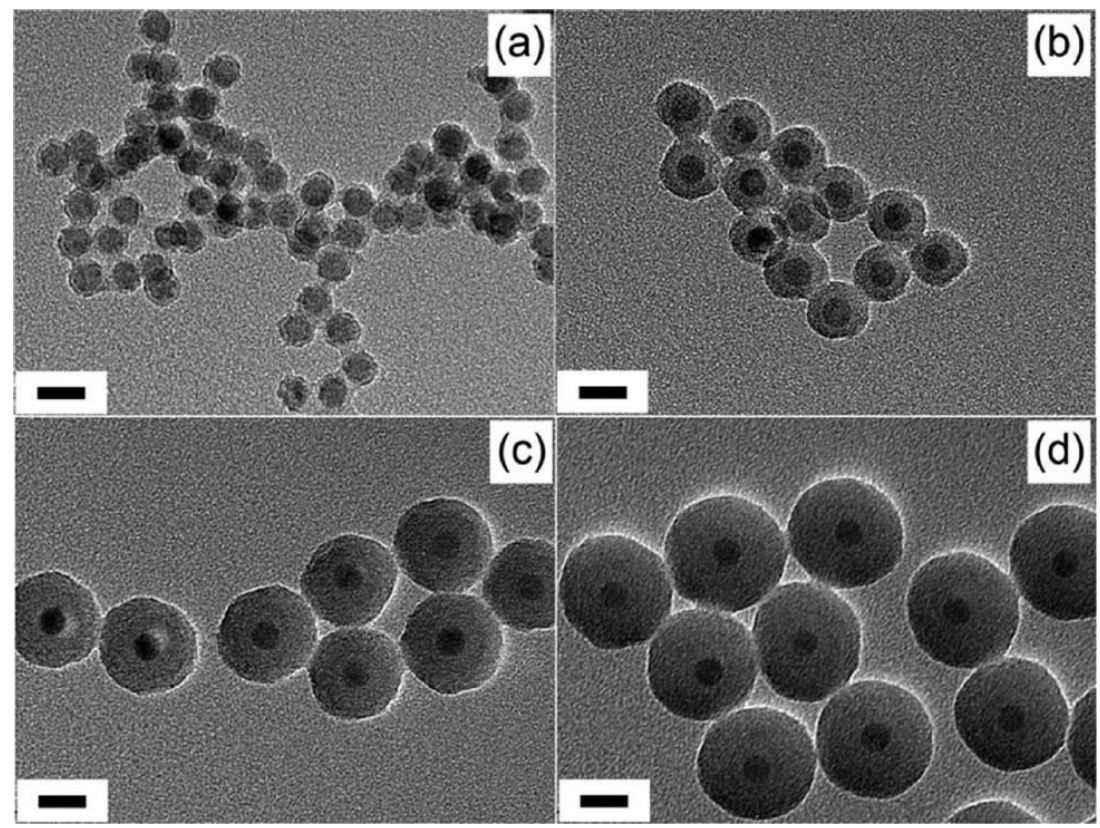

Figure 2. Transmission electron microscope (TEM) image of 12.2-nm $\mathrm{Fe}_{3} \mathrm{O}_{4} @ \mathrm{SiO}_{2}$ nanoparticles (NPs) with shell thicknesses of (a) $2.0 \mathrm{~nm}$, (b) $6.3 \mathrm{~nm}$, (c) $14.1 \mathrm{~nm}$, and (d) $19.8 \mathrm{~nm}$. Scale bar = $20 \mathrm{~nm}$. Reproduced with permission from [65]. Copyright American Chemical Society, 2012. 


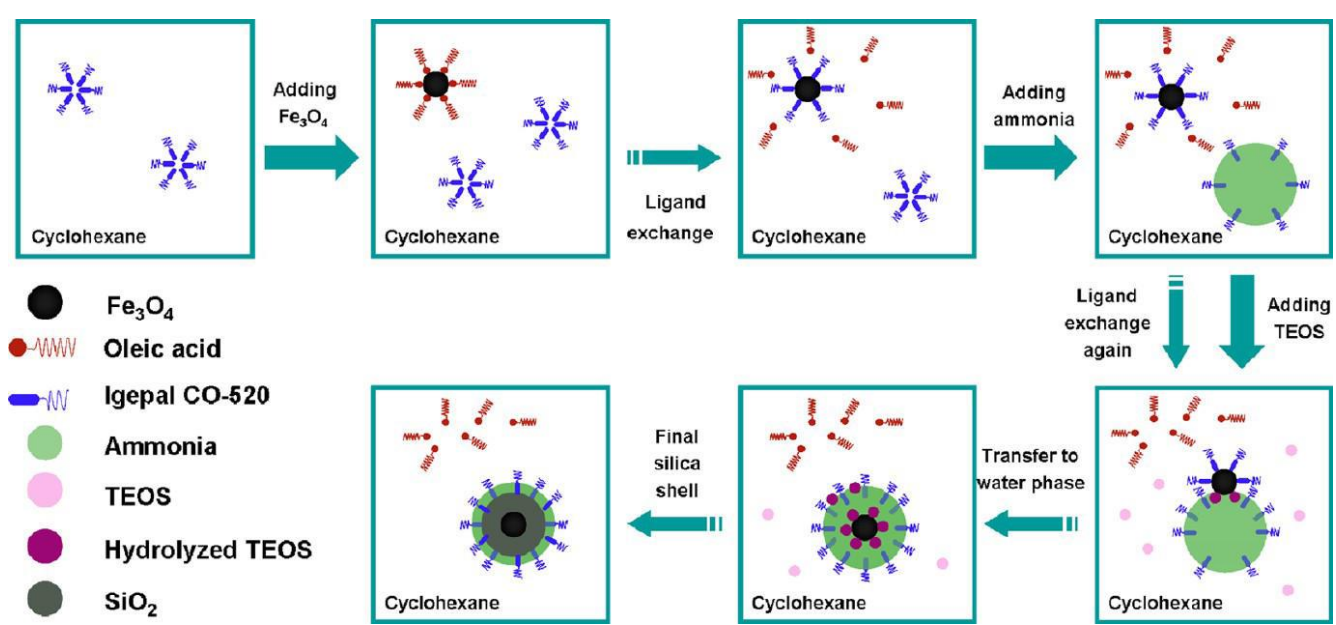

Figure 3. Illustration of the coating mechanism of $\mathrm{SiO}_{2}$ on the Surface of $\mathrm{Fe}_{3} \mathrm{O}_{4} \mathrm{NPs}$. Reproduced with permission from [62]. Copyright American Chemical Society, 2012.

The third method is aerosol pyrolysis, which is very innovative, highly productive and usually carried out in a flame environment $[50,67]$. Flame aerosol technology is widely used in large-scale production of carbon black and ceramic products such as fumed silica and titania [68], as well as zinc oxide and alumina powders [69,70]. Professor Pratsinis' group has done a lot of research and made outstanding contributions in this field $[69,71]$. He developed the flame spray pyrolysis process for the aerosol synthesis of films and particles up to $5 \mathrm{~kg} / \mathrm{h}$ in his labs. He has shown experimentally how to closely control aerosol particle size, crystallinity and morphology, from perfectly spherical to highly ramified fractal-like structures. Recently, his group published an article about the impact of humidity on silica nanoparticle agglomerate morphology and size distribution [72]. He studied scalable flame synthesis of $\mathrm{SiO}_{2}$ nanowires [68]. For example, Teleki et al. synthesized the IONPs by flame spray pyrolysis of acetylacetone iron in a xylene/acetonitrile solution, then in situ coated the resulting aerosol with $\mathrm{SiO}_{2}$ by oxidation of swirling hexamethlydisiloxane vapor. They eventually obtained hermetically-coated superparamagnetic $\mathrm{Fe}_{2} \mathrm{O}_{3} \mathrm{NPs}$ with a relatively low $\mathrm{SiO}_{2}$ content [73]. $\mathrm{Li}$ et al. reported double-faced $\gamma-\mathrm{Fe}_{2} \mathrm{O}_{3} @ \mathrm{SiO}_{2}$ nanohybrids with a "Janus" structure synthesized by a flame aerosol route. The aerosol route steps are illustrated in Scheme 1 [67].

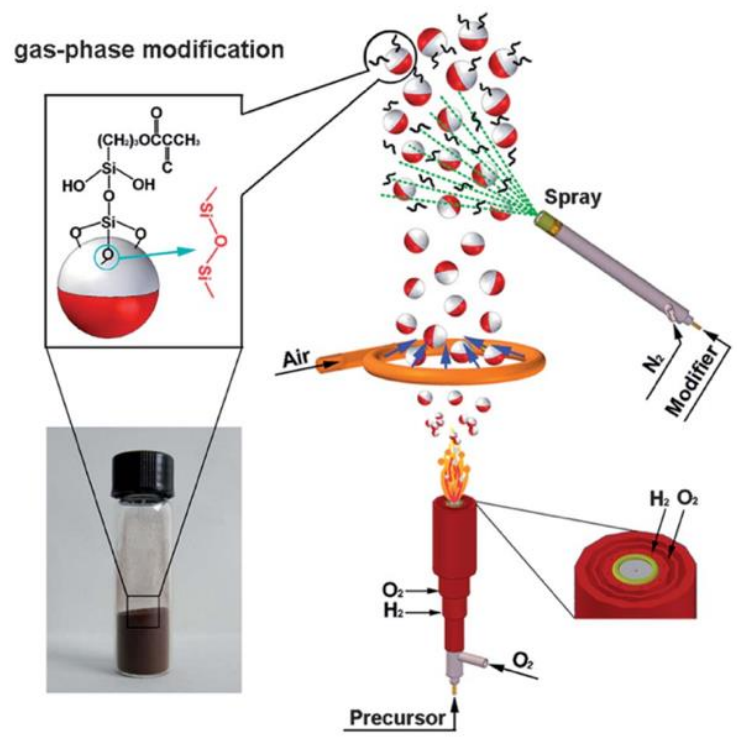

Scheme 1. Schematic illustration of flame synthesis and in situ selective modification of double-faced $\mathrm{g}-\mathrm{Fe}_{2} \mathrm{O}_{3}|| \mathrm{SiO}_{2} \mathrm{NHs}$. Reproduced with permission from [67]. Copyright Royal Society of Chemistry, 2013. 
The fourth method is based on sodium silicate solution, which is used as a silica precursor [74,75]. Setyawan et al. reported a strategy for synthesizing silica-coated magnetite NPs by the one-step electrochemical method. In the experimental system, sodium silicate serves as a dispersant and supporting electrolyte which helps to improve the conductivity of the solution. The anode and cathode of a chemical cell consists of iron and iron base, respectively [74,76]. Fajaroh et al. found that the concentration of sodium silicate solution has a positive and negative correlation with the crystallinity and surface area of the NPs, respectively [77].

Finally, a large number of reactive silanol groups present on the silica layer can be used for further surface functionalization [78]. (3-aminopropyl)triethoxysilane (APTES), (3-Mercaptopropyl)triMethoxysilane (MPTS), Triethoxy vinyl silanes (VTES), aminosilane are the most commonly used binding ligands. Functionalized $\mathrm{Fe}_{3} \mathrm{O}_{4} @ \mathrm{SiO}_{2}$ MNPs have great applications in biomedicine and environmental fields [79-81].

\subsubsection{Carbon}

Carbon-based materials as an inorganic compound are also used in surface coating of IONPs, to enhance their stability, biocompatibility and disperstivity. The $\mathrm{Fe}_{3} \mathrm{O}_{4} @ \mathrm{C}$ nanocomposites have various applications, such as use as catalysts, electrode supercapacitors, microwave absorbers, anode materials for lithium-ion batteries, and so on [82-86].

Many research groups have shown that $\mathrm{Fe}_{3} \mathrm{O}_{4} @ \mathrm{C}$ nanocomposites are the superior materials for supercapacitors [87]. For instance, Liu et al. synthesized carbon-coated $\mathrm{Fe}_{3} \mathrm{O}_{4}$ nanorods via hydrothermal reactions followed by a carbon-thermal reduction process, and demonstrated that $\mathrm{Fe}_{3} \mathrm{O}_{4} / \mathrm{C}$ nanorods exhibit higher specific capacitance as well as better cycle performance to that of pure $\mathrm{Fe}_{3} \mathrm{O}_{4}$. Generally this phenomenon arises due to the presence of a carbon layer that makes the particles intact and increases the electronic conductivity of the electrodes [88]. Sinan et al. synthesized $\mathrm{Fe}_{3} \mathrm{O}_{4}$ NPs by a co-precipitation method first and then successfully prepared layered porous $\mathrm{Fe}_{3} \mathrm{O}_{4} / \mathrm{C}$ nanocomposites with high specific surface area by hydrothermal carbonization and the $\mathrm{MgO}$ template method. This showed that $\mathrm{Fe}_{3} \mathrm{O}_{4} / \mathrm{C}$ nanocomposites are very promising for applications as a negative material for asymmetric supercapacitors [89]. Research shows that the presence of activated carbon with a three-dimensional (3D) network structure can enhance the conductivity and cycling stability of $\mathrm{Fe}_{3} \mathrm{O}_{4}$ [90].

$\mathrm{Fe}_{3} \mathrm{O}_{4} @ \mathrm{~N}$-doped carbon NPs have great importance in lithium-ion batteries as an efficient oxygen-reduction electrocatalyst [91,92]. Number of materials can be used as $\mathrm{N}$ and $\mathrm{C}$ sources. For example, Yang et al. fabricated yolk-shell $\mathrm{Fe}_{3} \mathrm{O}_{4} @$ Void@C-N NPs by using melamine formaldehyde resin [93]. Similarly, Yang et al. prepared $\mathrm{Fe}_{3} \mathrm{O}_{4} @$ void@N-doped carbon with a yolk-shell structure where $\mathrm{C}$ and $\mathrm{N}$ are provided by ionic liquids. The introduction of nitrogen helps to enhance the lithium ion storage capacity, and the void acts as a buffer during the charging and discharging process [94]. $\mathrm{Fe}_{3} \mathrm{O}_{4} @ \mathrm{~N}$-doped carbon NPs can also be used as an oxygen-reduction electrocatalyst $[95,96]$.

Carbon nanotubes are one-dimensional nanomaterials made by curling one or more layers of graphite sheets in a certain way. Carbon nanotubes are widely fabricated as nanocomposites because of their metal-semiconductor characteristics, high mechanical strength, excellent adsorption capacity and microwave absorption capacity [97-100]. Guo et al. synthesized $\mathrm{Fe}_{3} \mathrm{O}_{4} / \mathrm{CNTs}$ nanocomposites with particle size of $80 \mathrm{~nm}$ via the hydrothermal method by using $\mathrm{Sn}(\mathrm{OH})_{6}{ }^{2-}$ as an inorganic dispersant. After 50 cycles, the $\mathrm{Fe}_{3} \mathrm{O}_{4} / \mathrm{CNTs}$ nanocomposites can provide reversible discharge capacity of $700 \mathrm{mAh} / \mathrm{g}$ at the $50 \mathrm{~mA} / \mathrm{g}$ current density [101]. Zhu et al. synthesized $\mathrm{Fe}_{3} \mathrm{O}_{4} / \mathrm{CNTs}$ nanocomposites with 3D network by anchoring porous $\mathrm{Fe}_{3} \mathrm{O}_{4}$ spheres onto carbon nanotubes. This nanocomposite exhibits a remarkable microwave absorption property [102]. Zhang et al. prepared $\mathrm{Fe}_{3} \mathrm{O}_{4} / \mathrm{CNTs}$ nanocomposites by thermal decomposition of polyols, and conjugated these with hexanediamine and used them as a dual-drug carrier for the co-delivery of epirubicin hydrochloride and paclitaxel. Their designed $\mathrm{Fe}_{3} \mathrm{O}_{4} / \mathrm{CNTs}$ nanocomposites have potential applications in cancer treatment as a combined chemotherapy approach [103]. 
$\mathrm{Fe}_{3} \mathrm{O}_{4}$ /graphene nanocomposites have drawn much attention in recent years [50,104]. Their superior properties have seen them widely applied in lithium batteries, ion removal, dye removal, catalysts, sensors, supercapacitor electrodes, microwave absorption, MRI, etc. [105-112]. Kumar et al. synthesized a 3D hybrid material composed of $\mathrm{Fe}_{3} \mathrm{O}_{4}$ NPs and reduced graphene oxide (rGO) nanosheets, in which $\mathrm{Fe}_{3} \mathrm{O}_{4}$ nanoparticles were introduced into the network of rGO nanosheets, and the formation mechanism is shown in Scheme 2. The specific capacitance of this hybrid material is determined by the surface morphology and interconnection of the two components [113]. A novel sandwich-structured graphene- $\mathrm{Fe}_{3} \mathrm{O}_{4}$ composites (graphene- $\mathrm{Fe}_{3} \mathrm{O}_{4} @$ carbon) were prepared by Zhao et al., with higher reversible capacity, better cycling/rate performance than carbon-coated $\mathrm{Fe}_{3} \mathrm{O}_{4}$. The carbon layer serves as a buffer, while avoiding the aggregation of nanoparticles [114].

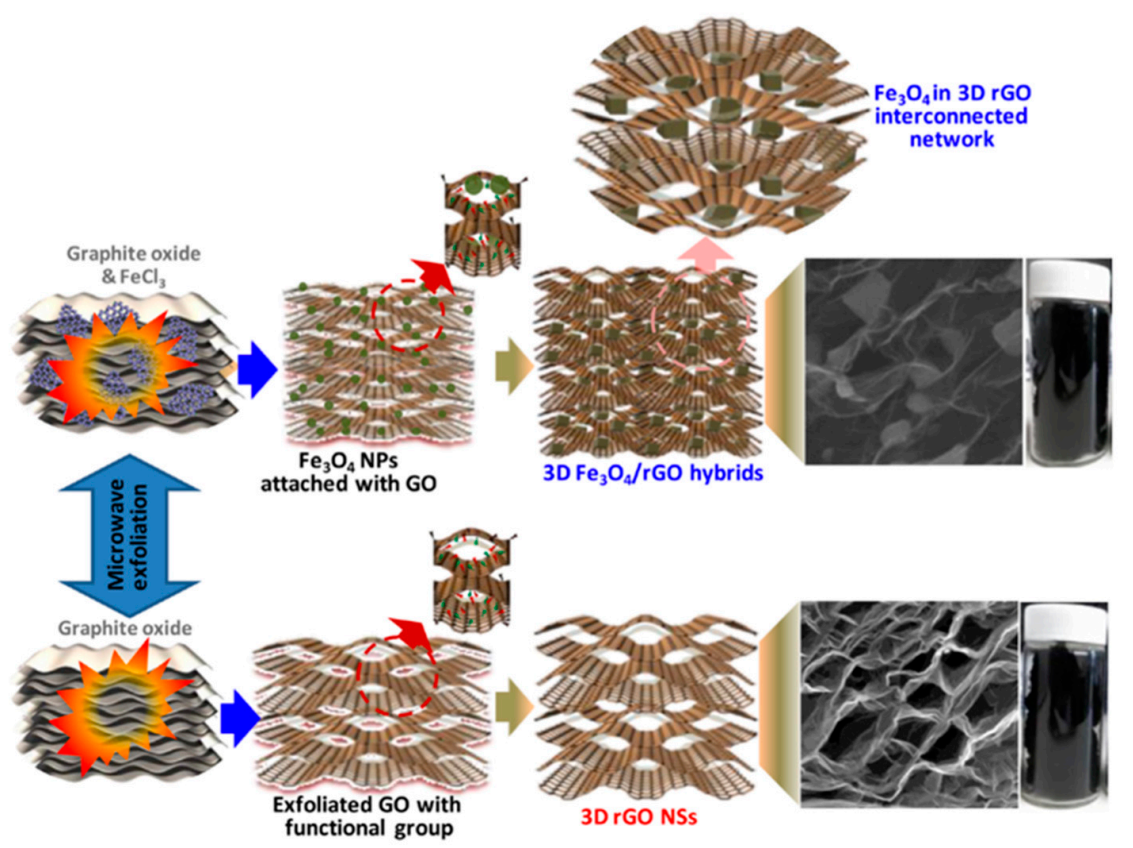

Scheme 2. Schematic formation mechanism of three-dimensional $\mathrm{Fe}_{3} \mathrm{O}_{4} / \mathrm{rGO}$ hybrids. Reproduced with permission from [113]. Copyright American Chemical Society, 2017.

\subsubsection{Metal}

Surface modification of IONPS with metallic elements can provide an inert layer, which typically exhibit a core-shell, core-satellite or dumbbell structure. Metallic coatings facilitate further functionalization of the IONPS to improve stability and compatibility [115].

Gold is the most common noble metal element used for surface coating [116-119]. In general, direct and indirect method are the two routes to achieve the gold shell coating on the surface of the magnetic IONPs, as shown in Scheme 3 [120].

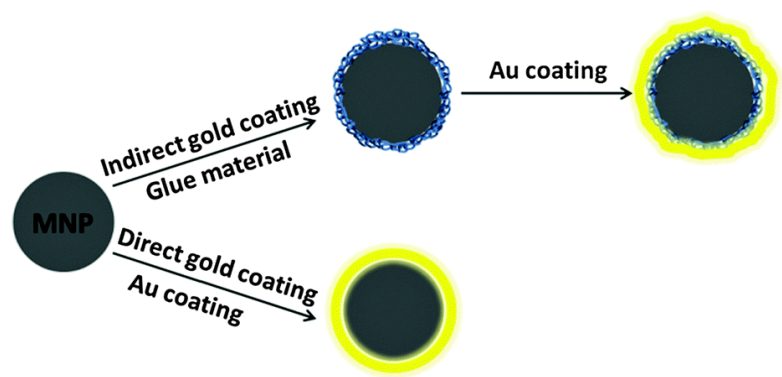

Scheme 3. Schematic illustration of the two routes for gold coating. Reproduced with permission from [120]. Copyright Royal Society of Chemistry, 2016. 
A direct method is to directly form a gold shell onto the surface of IONPs via reduction of $\mathrm{Au}_{3}{ }^{+}$ by using reducing agents. Direct gold coating can be carried out in aqueous or organic solution. In the aqueous phase, the sodium citrate and sodium borohydride are the frequently used reducing agents [116,121]. Ghorbani et al. synthesized the citrate-protected $\mathrm{Fe}_{3} \mathrm{O}_{4} / \mathrm{Au}$ NPs by the method of Lo. First, $\mathrm{HAuCl}_{4}$ was added to deionized water and heated to boiling. After that, the prepared $\mathrm{Fe}_{3} \mathrm{O}_{4}$ nanoparticle solution was added, followed by the insertion of sodium citrate under stirring. Finally, the mixture was boiled under stirring for $5 \mathrm{~min}$ and in doing so the solution color changed from brown to burgundy [122,123]. Yan et al. synthesized the carboxylate-functionalized $\mathrm{Fe}_{3} \mathrm{O}_{4} \mathrm{NPs}_{\text {by }}$ a one-step method and subsequently mixed it with $\mathrm{HAuCl}_{4}$ aquatic solution. Then added $\mathrm{NaBH}_{4}$ to the mixed solution to directly reduce the $\mathrm{HAuCl}_{4}$. Inspired by the experimental results, they put forward a mechanism to synthesize bifunctional $\mathrm{Fe}_{3} \mathrm{O}_{4} @ \mathrm{Au}$ nanocomposites, as shown in Scheme 4. Carboxylic acid groups adsorbed $\mathrm{AuCl}_{4}$ under acidic condition, and then $\mathrm{NaBH}_{4}$ was added to form zero-valent $\mathrm{Au}$ which attached to $\mathrm{Fe}_{3} \mathrm{O}_{4} \mathrm{NPs}$ through the chemistry of the carboxylate group, and gradually the gold shell was formed around $\mathrm{Fe}_{3} \mathrm{O}_{4}$ NPs [124]. Hydroxylamine hydrochloride is another reducing agent used [125].

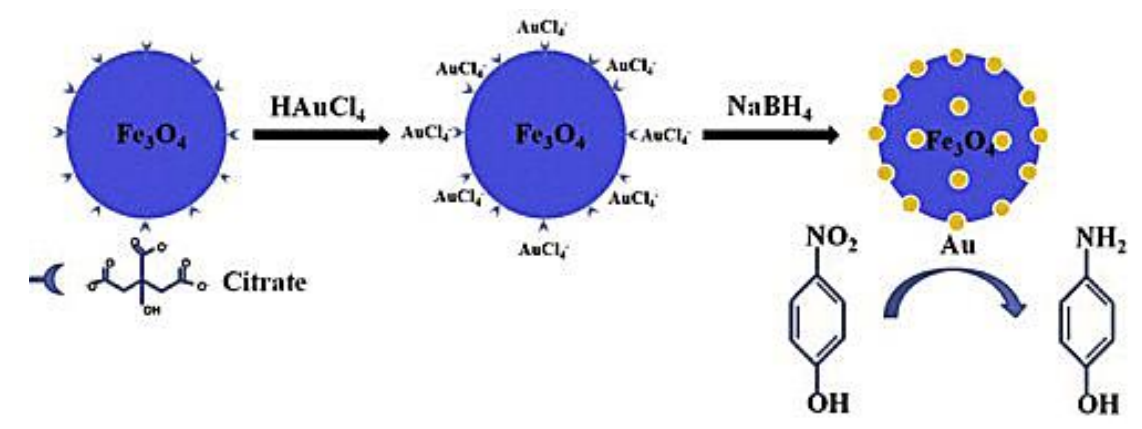

Scheme 4. Schematic illustration of the bifunctional $\mathrm{Fe}_{3} \mathrm{O}_{4} / \mathrm{Au}$ nanocomposites. Reproduced with permission from [124]. Copyright Elsevier, 2014.

In the organic synthesis route, the oleic acid and oleylamine are usually present as a capping agent in the solution. Freitas et al. used 1-hexadecanol to reduce $\mathrm{Fe}(\mathrm{acac})_{3}$ for amine-functionalized $\mathrm{Fe}_{3} \mathrm{O}_{4}$ NPs in the presence of oleic acid and oleylamine. Oleylamine also works as a reducing agent. These amine groups can attach $\mathrm{Au}^{3+}$. Then, they synthesized core-shell $\mathrm{Fe}_{3} \mathrm{O}_{4} @ \mathrm{Au} \mathrm{MNPs}$ in three $\mathrm{Fe}_{3} \mathrm{O}_{4}: \mathrm{HAuCl}_{4}$ molar ratios $(1: 1 ; 1: 4 ; 1: 7)$. Their results show that the gold shell formed in a ratio of 1:1 cannot completely encase the $\mathrm{Fe}_{3} \mathrm{O}_{4}$ core, while $\mathrm{Fe}_{3} \mathrm{O}_{4} @ \mathrm{Au}$ obtained in a 1:4 ratio has the best performance [126]. $\mathrm{Li}$ and co-workers used the $\mathrm{FeO}(\mathrm{OH})$ and $\mathrm{HAuCl}_{4}$ as iron precursor and gold precursor, respectively. With the presence of oleic acid, octahedron-like $\mathrm{Au} / \mathrm{Fe}_{3} \mathrm{O}_{4} \mathrm{NPs}_{\text {were }}$ synthesized by reducing $\mathrm{FeO}(\mathrm{OH})$ and $\mathrm{HAuCl}_{4}$ in 1-octadecene solvent. The size of the synthesized particles is controlled by the proportion of the starting materials [127].

An indirect method is used to synthesize $\mathrm{Fe}_{3} \mathrm{O}_{4} @ \mathrm{Au}$ NPs by forming a "glue" layer between the IONPs core and the gold shell. The layer design and preparation are crucial during the synthesis as they can affect the properties of the $\mathrm{Fe}_{3} \mathrm{O}_{4} @ \mathrm{Au}$ NPs [128]. The "glue" layer should be capable of enhancing the $\mathrm{Fe}_{3} \mathrm{O}_{4}$ MNPs stability, and also have metal binding groups to attach gold seeds to promote the formation of gold shell. Materials used as the "glue" layer are often polymers, silica and carbon [129-132]. Wang et al. used the mercapto-silica shell as the "glue" layer combining the $\mathrm{Fe}_{3} \mathrm{O}_{4}$ core with the $\mathrm{Au}$ shell and obtained the durian-like multifunctional $\mathrm{Fe}_{3} \mathrm{O}_{4} @ \mathrm{Au}$ nanocomposites [129]. $\mathrm{Li}$ et al. synthesized amino-functionalized $\mathrm{Fe}_{3} \mathrm{O}_{4} @ \mathrm{SiO}_{2} \mathrm{NPs}$ firstly and then reduced $\mathrm{HAuCl}_{4}$ by a seed growth method to obtain $\mathrm{Fe}_{3} \mathrm{O}_{4} @ \mathrm{Au}$ NPs [130]. Polyphosphazene (PZS) as the "glue" layer has been studied. The steps involved in the preparation are shown in the Scheme 5 . These synthesized $\mathrm{Fe}_{3} \mathrm{O}_{4} @ \mathrm{PZS} @ \mathrm{Au}$ NPs has multiple functions for MRI and photothermal therapy, as well as the potential to be used as a biosensor and catalyst [131]. Ramos-Tejada et al. developed a new approach to synthesize $\mathrm{Fe}_{3} \mathrm{O}_{4} / \mathrm{Au}$ NPs. The first step involved mixing $\mathrm{FeSO}_{4}$ and distilled water, by adding $\mathrm{KNO}_{3}$ and $\mathrm{NaOH}$ 
in an oxygen-free environment at $90{ }^{\circ} \mathrm{C}$ to synthesize $\mathrm{Fe}_{3} \mathrm{O}_{4}$ core. The second step involved mixing MNP suspension with polyethylenimine (PEI) solution, by applying sonication to achieve a first PEI layer; subsequently a second poly(styrenesulfonate) (PSS) layer and a third PEI layer were added using a layer-by-layer techniques. The third step involved using $\mathrm{NaBH}_{4}$ to reduce chloroauric acid to obtain negatively charged gold NPs. In a fourth step, the previously obtained polymer-coated NPs were dispersed in water until the particle concentration was $0.25 \mathrm{mg} / \mathrm{mL}$, by adding the resulting suspension dropwise to the gold seed solution, after sonication and subsequent further treatment, $\mathrm{Fe}_{3} \mathrm{O}_{4} / \mathrm{Au}$ NPs were finally obtained [133].

Silver is another noble metal used for surface coating. Silver coated magnetic $\left(\mathrm{Fe}_{3} \mathrm{O}_{4} @ \mathrm{Ag}\right) \mathrm{NPs}$ have appealing applications in the field of biomedicine [134,135]. Chen et al. prepared the $\mathrm{Ag} @ \mathrm{Fe}_{3} \mathrm{O}_{4}$ nanowire by the solvothermal method and the showed that these NPs possessed peroxidase-like catalyst activity, which makes them suitable candidates for biomedicine [136]. Gao et al.'s experiments on mice demonstrated that $\mathrm{Fe}_{3} \mathrm{O}_{4} @ \mathrm{Ag}$ hybrid NPs are effective computed tomography (CT) contrast agents, and thus can be used for in vivo CT imaging [137]. Du et al. reported a portable SERS (surface enhanced Raman scattering) sensor based on $\mathrm{Fe}_{3} \mathrm{O}_{4} @ \mathrm{Ag}$ core-shell NPs to distinguish arsenic species [138].

On the other hand, silver-coated magnetic nanocomposites are considered as promising multifunctional materials as well because they have unique antibacterial characteristics [139-142]. However, hybrid $\mathrm{Fe}_{3} \mathrm{O}_{4} @ \mathrm{C} @ \mathrm{Ag}$ are the dominant class of nanocomposites owing to their widespread applications in different research areas [143-145]. Xia et al. synthesized $\mathrm{Fe}_{3} \mathrm{O}_{4} @ \mathrm{C} @ \mathrm{Ag}$ nanocomposites and concluded that by introducing a carbon layer, their synthesized nanocomposites have better antibacterial activity compared to $\mathrm{Fe}_{3} \mathrm{O}_{4} @ \mathrm{Ag}$. Thus the hybrid $\mathrm{Fe}_{3} \mathrm{O}_{4} @ \mathrm{C} @ \mathrm{Ag}$ can be used as catalysts, antibacterial agents, adsorbents and bi-functional magneto-optical probes [146]. Chen et al. reported a multifunctional system based on $\mathrm{Fe}_{3} \mathrm{O}_{4} @ \mathrm{C} @ \mathrm{Ag}$ hybrid NPs that can be used as a bi-functional probe for MRI and two-photon fluorescence (TPF) imaging techniques as well as near-infrared light responsive drug delivery [147].

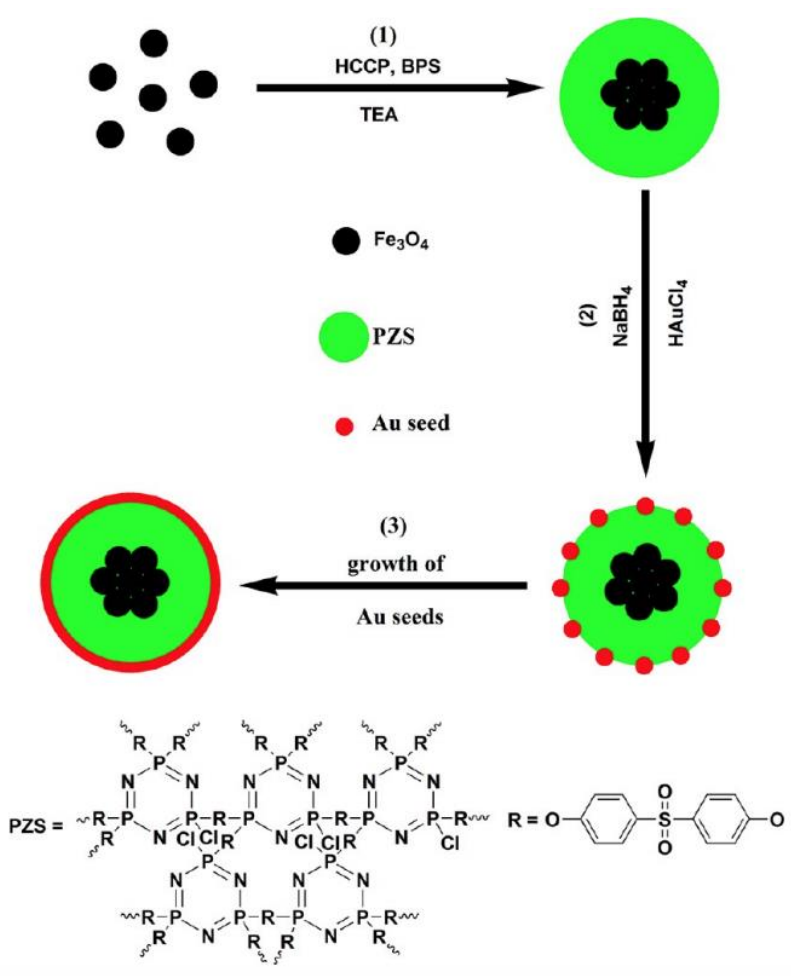

Scheme 5. Preparation procedure of $\mathrm{Fe}_{3} \mathrm{O}_{4} @ P Z S @ A u$ shells. Reproduced with permission from [131]. Copyright American Chemical Society, 2013. 


\subsubsection{Metal Oxides/Sulfides}

Distinctive physicochemical properties of metal oxides and metal sulfides are of great interest in the functionalization of IONPs $[50,148]$. Generally, by considering the structure, the metal oxides are divided into six main categories such as $\mathrm{M}_{2} \mathrm{O}\left(\mathrm{Cu}_{2} \mathrm{O}, \mathrm{Ag}_{2} \mathrm{O}\right.$ etc.), $\mathrm{MO}(\mathrm{ZnO}, \mathrm{MgO}, \mathrm{CoO}, \mathrm{ZnS}$, CdS etc.), $\mathrm{M}_{2} \mathrm{O}_{3}\left(\mathrm{Al}_{2} \mathrm{O}_{3}, \mathrm{Y}_{2} \mathrm{O}_{3}, \mathrm{Bi}_{2} \mathrm{~S}_{3}\right.$ etc.), $\mathrm{MO}_{2}\left(\mathrm{TiO}_{2}, \mathrm{SnO}_{2}\right.$ etc.), $\mathrm{M}_{2} \mathrm{O}_{5}\left(\mathrm{~V}_{2} \mathrm{O}_{5}\right.$ etc. $)$ and $\mathrm{MO}_{3}$ $\left(\mathrm{WO}_{3}, \mathrm{MoO}_{3}\right.$ etc.). Saffari prepared superparamagnetic $\mathrm{Fe}_{3} \mathrm{O}_{4}-\mathrm{ZnO}$ nanocomposites with $10 \% \mathrm{ZnO}$ content by adopting the sonochemical method and reported that $\mathrm{Fe}_{3} \mathrm{O}_{4} / \mathrm{ZnO}$ nanocomposite has excellent photocatalytic properties. Through the degradation analysis of eight kinds of organic dyes, it was found that $\mathrm{Fe}_{3} \mathrm{O}_{4} / \mathrm{ZnO}$ nanocomposite has suitable photocatalytic properties. Moreover, the $\mathrm{Fe}_{3} \mathrm{O}_{4} @ \mathrm{ZnO}$ core/shell NPs have enhanced photocatalytic performance compared to bare $\mathrm{ZnO}$ NPs [149]. Wang's group prepared the reusable $\mathrm{Fe}_{3} \mathrm{O}_{4} @ \mathrm{ZnO}$ core/shell NPs and studied their photo-catalytic characteristics. According to the photocatalytic reaction mechanism of the $\mathrm{Fe}_{3} \mathrm{O}_{4} @ \mathrm{ZnO}$ (Scheme 6), they attributed this phenomenon to the higher surface oxygen vacancy concentration and the inhibition of photo-induced electron-hole pairs recombination by $\mathrm{Fe}^{3+}$ ions [150]. Recently, Shekofteh-Gohari et al. fabricated a new type of magnetically separable $\mathrm{Fe}_{3} \mathrm{O}_{4} / \mathrm{ZnO} / \mathrm{CoWO}_{4}$ nanocomposites with a different ratio of $\mathrm{CoWO}_{4}$. When the ratio of $\mathrm{CoWO}_{4}$ is $30 \%$, the nanocomposites showed excellent photocatalytic activity. In terms of the degradation rate constant of rhodamine $\mathrm{B}$, the optimum nanocomposites were 24 and 5 times higher than in the absence of laser source or the untreated samples of $\mathrm{Fe}_{3} \mathrm{O}_{4} / \mathrm{ZnO}$ and $\mathrm{Fe}_{3} \mathrm{O}_{4} / \mathrm{CoWO}_{4}$ samples, respectively [151]. In addition, $\mathrm{Fe}_{3} \mathrm{O}_{4} / \mathrm{Al}_{2} \mathrm{O}_{3}$ NPs can be used as adsorbents to remove ions in water. Doping with sulfate can be used to remove $\mathrm{F}^{-}$in drinking water. A fluoride adsorption process was rapid in the beginning while slower as the passage of time; nearly $90 \%$ adsorption was achieved within 20 min [152]. Similarly, in another study, the $\mathrm{Fe}_{3} \mathrm{O}_{4} @ \mathrm{TiO}_{2}$ core-shell magnetic composites were used as sorbents to efficiently sorb uranium (VI) [153]. Moreover, Liu et al. found that the $\mathrm{Fe}_{3} \mathrm{O}_{4} @ \mathrm{TiO}_{2}$ with a yolk-shell structure has enhanced microwave absorption performance than that with a core-shell structure [154].

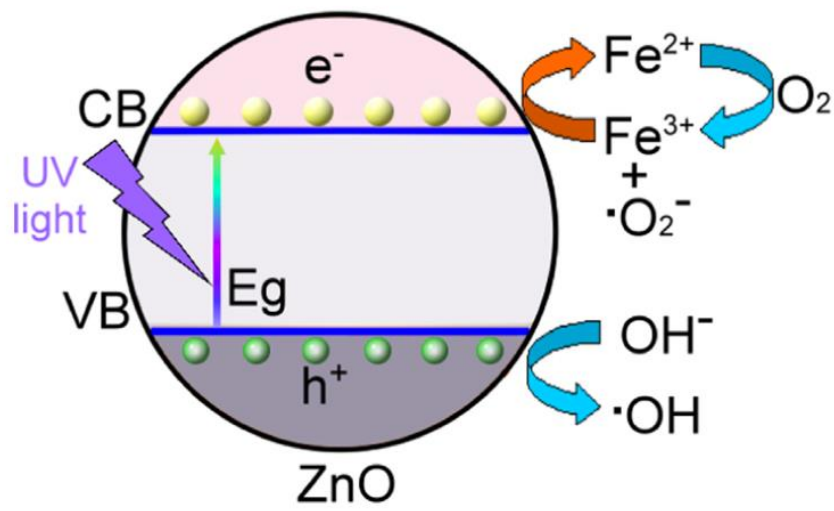

Scheme 6. A proposed photocatalytic reaction mechanism of the $\mathrm{Fe}_{3} \mathrm{O}_{4} @ \mathrm{ZnO}$. Reproduced with permission from [150]. Copyright Elsevier, 2014.

Generally, the combination of hard and soft magnetics will lead to many new applications [155]. Hard-soft magnetic composites are widely used in permanent magnets, data storage systems, image contrast agents and microwave devices [156]. In these bi-magnetic nanostructures, the size of the soft phase often determines the magnetization switch behavior. A typical example is the combination of hard magnetic $\mathrm{CoFe}_{2} \mathrm{O}_{4}$ and soft magnetic $\mathrm{Fe}_{3} \mathrm{O}_{4}$ [157,158]. Zeng et al. reported that composites $\left(\mathrm{CoFe}_{2} \mathrm{O}_{4} / \mathrm{Fe}_{3} \mathrm{O}_{4}\right)$ have larger remanence (Mr/Ms), coercivity $(\mathrm{Hc})$ and maximum energy product (BH)max than pure ferrite $\left(\mathrm{CoFe}_{2} \mathrm{O}_{4}\right)$ due to exchange coupling [156,159]. 


\subsection{Surface Coating with Organic Materials}

\subsubsection{Polymers}

In recent years, polymer-coated IONPs have drawn much more attention owing to their widespread applications in various research areas including nanomedicine. In situ and post-annealing coating are two common approaches to synthesize polymer coated IONPs [78]. The former is coating the polymer onto the surface of IONPs during the synthesis process [160]. The latter is further polymer functionalized on the basis of previously prepared IONPs. Todate, dextran, chitosan, alginate, polyethylene glycol (PEG), polyvinyl alcohol (PVA), polydopamine (PDA), polysaccharide, polyethylenimine, polyvinylpyrrolidone (PVP), poly acid polyetherimide, and polyamidoamine (PAMAM) are the most commonly used polymers for the surface modification of IONPs (Table 3) [161-171].

Table 3. Polymers used for coating IONPs and their applications.

\begin{tabular}{|c|c|c|}
\hline Polymer & Source/Production/Preparation & Applications \\
\hline $\begin{array}{l}\text { Polyethylene glycol } \\
\text { (PEG) }\end{array}$ & $\begin{array}{c}\text { Produced by the interaction of ethylene oxide } \\
\text { with water, ethylene glycol, or ethylene glycol } \\
\text { oligomers }\end{array}$ & $\begin{array}{l}\text { Magnetic resonance imaging } \\
\text { (MRI) contrast agents for } \\
\text { in vivo cancer imaging, } \\
\text { biosensors }\end{array}$ \\
\hline $\begin{array}{l}\text { Polyvinylvinyl } \\
\text { pyrrolidone (PVP) }\end{array}$ & Made from the monomer N-vinylpyrrolidone & $\begin{array}{l}\text { Targeted killing of breast } \\
\text { cancer cells, MRI contrast } \\
\text { agents }\end{array}$ \\
\hline $\begin{array}{l}\text { Polyethylenimine } \\
\text { (PEI) }\end{array}$ & $\begin{array}{l}\text { Branched PEI: by the ring opening } \\
\text { polymerization of aziridine } \\
\text { Linear PEI: by post-modification of other } \\
\text { polymers like poly(2-oxazolines) or } \\
\text { N-substituted polyaziridines }\end{array}$ & $\begin{array}{l}\text { Cancer cell separation, } \\
\text { hyperthermia }\end{array}$ \\
\hline Polyacrylic acids & Polymerization of acrylic acid & Anticancer drug delivery \\
\hline $\begin{array}{l}\text { Polyvinyl alcohol } \\
\text { (PVA) }\end{array}$ & $\begin{array}{l}\text { Polymerization of vinyl acetate, } \\
\text { then saponification of polyvinyl acetate }\end{array}$ & $\begin{array}{l}\text { In vivo imaging, drug delivery, } \\
\text { biosensor }\end{array}$ \\
\hline Polydopamine (PDA) & Formed from dopamine at slightly basic $\mathrm{pH}$ & $\begin{array}{l}\text { Catalyst and adsorbent, } \\
\text { biosensors }\end{array}$ \\
\hline Dextran & Produced by lactic acid bacteria & $\begin{array}{l}\text { In vivo cancer drug carriers, } \\
\text { MRI contrast agents }\end{array}$ \\
\hline Chitosan & Extracted from shellfish or fungi cell wall & $\begin{array}{l}\text { Hyperthermia, tissue } \\
\text { engineering }\end{array}$ \\
\hline Starch & Produced by green plants & Contrasting and imaging \\
\hline Alginate & Extracted from brown algae & $\begin{array}{l}\text { Drug-targeted controlled } \\
\text { release, adsorbent }\end{array}$ \\
\hline Polyphenol & $\begin{array}{l}\text { Found in some common plant foods like cocoa } \\
\text { beans, tea and vegetables }\end{array}$ & Magnetic hyperthermia \\
\hline Flavonoids & $\begin{array}{l}\text { Found in some common plant foods like fruits, } \\
\text { vegetables, beans and tea }\end{array}$ & $\begin{array}{l}\text { Cell imaging, nano-carrier; } \\
\text { nano-drug }\end{array}$ \\
\hline Amino acids & In nature & $\begin{array}{l}\text { Adsorbent, radio-labeling, } \\
\text { biosensors and cancer } \\
\text { detection }\end{array}$ \\
\hline Lipids & In nature, animal food and nuts & $\begin{array}{l}\text { Gene therapy, dual-modal } \\
\text { imaging }\end{array}$ \\
\hline
\end{tabular}

Dextran is a polysaccharide with excellent biocompatibility as well as good water solubility and its coating onto the IONPs has an impact on their physicochemical properties. Shaterabadi et al. found that dextran coating reduces the saturation magnetization of the IONPs which is mainly due to the presence 
of dextran non-magnetic shell. Moreover, the dextran coating also reduces the cytotoxicity of the IONPs, therefore making the nanocarrier excellent while enhancing their biocompatibility [160]. In addition, Hauser et al. found that synthetic methods, the amount of dextran can greatly affect the properties of the IONPs such as size, stability, crystallinity and magnetism [172]. Owing to its biosafety, bioactivity, biocompatibility, low cytotoxicity, dextran-coated IONPs are considered promising candidates for biomedical applications [173]. Unterweger et al. developed a novel drug delivery system by coating IONPs with dextran and cisplatin hyaluronic acid. After testing in the Jurkat cell line and the PC-3 cell line, the drug-free IONPs showed good biocompatibility and no cytotoxic effects, whereas the IONPs incorporated with cisplatin were able to induce apoptosis [174]. Osborne et al. synthesized dextran-coated IONPs which can be used as clinical MRI contrast agents in two-step and one-step procedures with the aid of microwaves. This method is simple, versatile, cost effective and repeatable. Therefore, the complexity of manufacturing processes is greatly resolved which makes the commercial production of surface modified IONPs possible [161].

PEG is another frequently-used water-soluble polymer. In the past, several methods and approaches have been reported to synthesize PEG-coated IONPs for the purpose of biomedical applications [164,175-177]. Liu et al. developed a simple strategy in which rich carboxyl groups were introduced through the multiple coordination between poly(acrylic acid) (PAA) and IONPs, then $\alpha$, $\omega$-diamino PEG was attached to IONPs by amidation of carboxyl groups. In vitro experiments showed that these surface-decorated IONPs significantly attenuated macrophage phagocytosis, as described by Lee's group [178,179]. Moreover, it is also reported PEG-coated $\mathrm{Fe}_{3} \mathrm{O}_{4} \mathrm{NPs}$ can prevent the reduction of cytochrome $\mathrm{C}$ [175]. Anbarasu et al. obtained $\mathrm{Fe}_{3} \mathrm{O}_{4}$ with a cubic inverse spinel structure by the coprecipitation method and found that both the average crystallite size and physical size of the NPs were decreased by increasing the amount of PEG [164]. Another synthesizing approach has been reported to prepare superparamagnetic IONPs with tunable properties using PEG containing PVP or PEI. An illustration of the synthesis of PEG/PVP-coated superparamagnetic iron oxide nanoparticles (SPIONs) is illustrated in Scheme 7. The prepared superparamagnetic IONPs had a hydrodynamic size less than $40 \mathrm{~nm}$, with neutral or positive zeta potentials, showed higher dispersion stability than those IONPs coated with PEG alone [180].

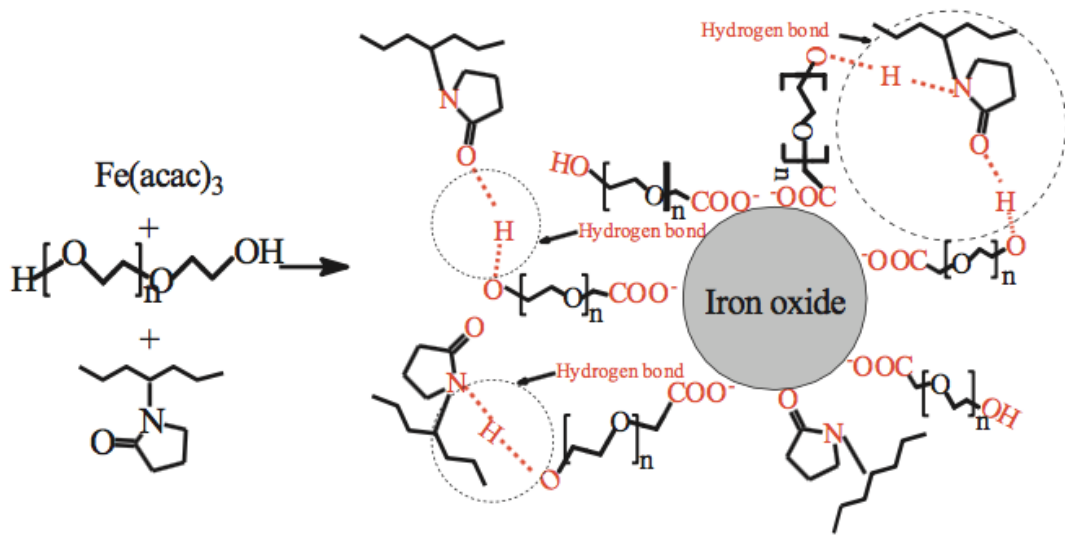

Scheme 7. Schematic illustration of the synthesis of PEG/PVP-coated superparamagnetic iron oxide nanoparticles (SPIONs). Reproduced with permission from [180]. Copyright Elsevier, 2013.

Chitosan is an alkaline hydrophilic polymer whose low toxicity, good biocompatibility and biodegradability is confirmed in reported work [162,181,182]. Chitosan-coated IONPs are usually further functionalized with other polymers such as PEG and PAA [183,184]. For instance, Yan et al. prepared chitosan-PAA coated magnetic composite microspheres and found that the addition of PAA significantly increased the adsorption capacity of $\mathrm{Cu}$ (II) [183]. Qu et al. loaded 10-hydroxycamptothecin (HCPT) onto prepared PEG-chitosan- $\mathrm{Fe}_{3} \mathrm{O}_{4}$ nanocomposites. The synthesis steps of PEG-chitosan- $\mathrm{Fe}_{3} \mathrm{O}_{4}$ nanocomposites are as follows. The chitosan- $\mathrm{Fe}_{3} \mathrm{O}_{4}$ was first dispersed in phosphate buffered 
saline. 1-ethyl-3-(3-dimethylaminopropyl) carbodiimide hydrochloride was then added to activate the carboxylic acid moiety of the subsequently added carboxymethylated PEG (CM-PEG). Next, the reaction mixture was stirred and cultured at room temperature for $48 \mathrm{~h}$. Thereafter, unreacted $\mathrm{CM}-\mathrm{PEG}$ was removed by centrifugation. Finally, $\mathrm{PEG}$-chitosan- $\mathrm{Fe}_{3} \mathrm{O}_{4}$ was washed three times with deionized water, collected by magnetic separation and lyophilized. Compared to the original HCPT powder, the HCPT-loaded nanocomposites showed higher antitumor activity against $\mathrm{HepG}_{2}$ cells. Besides, there nanocomposites can also be used for targeted hyperthermia [184]. However, the use of pure chitosan is limited due to its low solubility in acidic averments, low mechanical and thermal stability. Therefore, the researchers are trying to use the chitosan derivatives in order to overcome the aforementioned drawbacks of pure chitosan. N, O-carboxymethyl chitosan (CC) as a kind of chitosan carboxylation product has a good application prospect in membrane-forming. The membrane modified with CC- $\mathrm{Fe}_{3} \mathrm{O}_{4}$ NPs has improved hydrophilicity and anti-fouling properties [185].

Other polymers like polydopamine, polysaccharides, polylactic acid, polyacrylic acid, alginate, polyvinylidene fluoride, PEI, PVP, and PAMAM are also commonly used in surface conjugation of IONPs [186-188]. Recently, a new method based on cathodic electrochemical deposition (CED) and in situ coating was developed to prepare polysaccharide-coated $\mathrm{Fe}_{3} \mathrm{O}_{4}$ NPs [167]. PEI-coated IONPs can be further carboxylated or acetylated to enhance their biocompatibility [189]. PDA-coated $\mathrm{Fe}_{3} \mathrm{O}_{4} \mathrm{NPs}$ can be used to detect small molecule pollutants [166]. Bian et al. formed $\mathrm{Fe}_{3} \mathrm{O}_{4} @ P D A-P t$ composite by depositing Pt dendrimer-like NPs in situ on $\mathrm{Fe}_{3} \mathrm{O}_{4} @ P D A$ core-shell nanocomposites. This composite exhibited high catalytic performance for methylene blue, 4-nitrophenol and its derivative. It is worth mentioning that as a catalyst, it has good reusability and high stability [190]. Dimethyl sulfoxide (DMSO) can be used as a stabilizer to synthesize IONPs [191]. Yan et al. developed a novel potential MRI contrast agent by in situ synthesis of SPIO with immobilized SI-ATRP initiator and polymer analogs of DMSO. DMSO-based polymer acts to enhance the interaction between the MNPs and the water protons.

\subsubsection{Small Molecules and Surfactants}

Functionalized NPs can be divided into three main types: lipophilic, hydrophilic and amphiphilic. This form of division is based on different surface characteristics of such surface-coated NPs [155]. Inorganic compounds such as silane as a coupling agents can be used to bind the different functional groups (e.g., $-\mathrm{OH},-\mathrm{COOH},-\mathrm{NH}_{2},-\mathrm{SH}$ ) onto the surface of bare MNPs and further their conjugation with different biomolecules, metal ions and polymers in order to make these MNPs suitable for various applications in diverse research areas [50]. The mechanism of IONPs modified by silane agents is shown in Scheme 8 [155]. Briefly, 3-aminopropyltriethyloxysilane (APTES), mercaptopropyltriethoxysilane (MPTES), and triethoxyvinylsilane (VTES) are the common silane coupling agents used in the surface modification of IONPs. Wang et al. adopted the sonochemical method to prepare the APTES-coated $\mathrm{Fe}_{3} \mathrm{O}_{4}$ NPs with diameter $8.4 \pm 2.1 \mathrm{~nm}$ and concluded that the synthesized NPs exhibited superparamagnetism and good dispersibility. Magneto-rheological fluids prepared on the basis of these IONPs have typical magneto-rheological properties [192]. Li et al. developed acetylated APTES-coated $\mathrm{Fe}_{3} \mathrm{O}_{4}$ NPs based on the hydrothermal method. Based on their analysis results, they concluded that acetylation can improve the biocompatibility of NPs. The novel nanoparticle can be used for in vitro and in vivo MRI [193]. In addition, APTES functionalized magnetic iron oxide is also applied in the extraction of metal ions. In a study conducted by Mahmoud, it is reported that APTES functionalized $\mathrm{Fe}_{3} \mathrm{O}_{4}$ are capable of adsorbing $\mathrm{Pb}^{2+}, \mathrm{Cu}^{2+}, \mathrm{Cd}^{2+}$ and $\mathrm{Hg}^{2+}$ from aqueous solutions [194]. 


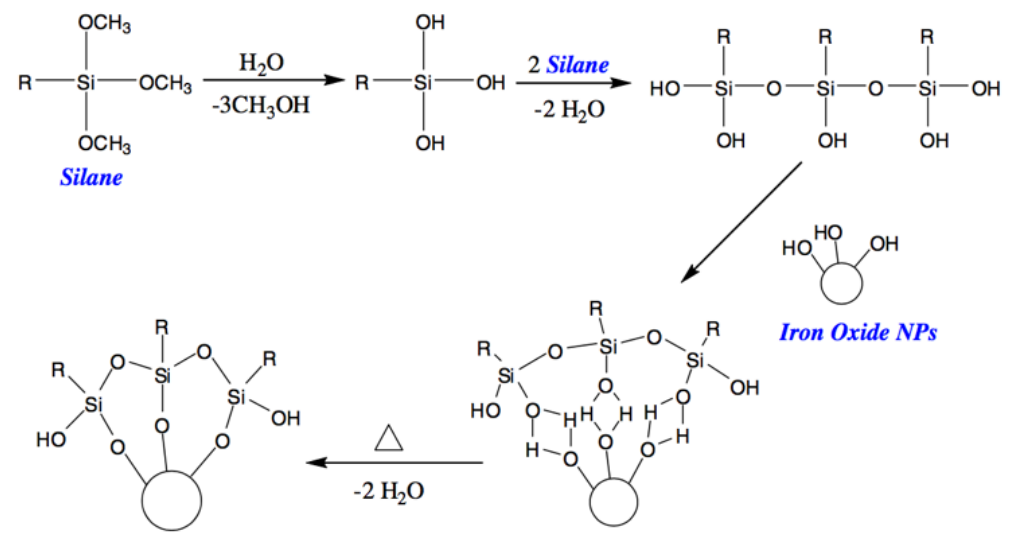

Scheme 8. Physicochemical mechanism for modifying the silane agents on the surface of iron oxide NPs. Reproduced with permission from [155]. Copyright Wei Wu, 2008.

Lipophilic substances such as oleic acid are typically referred to as "fat-loving" or "fat-liking" and are of great interest for researchers to prepare lipophilic IONPs with very good dissolvability in polar liquids such as oil $[195,196]$. Additionally, oleic acid can form a dense protective monolayer that binds firmly to the NPs surface to stabilize the NPs [197]. Recently, the high degree of monodispersity, excellent biocompatibility, low toxicity, high colloidal stability and hydrophobicity of different types of IONPs having surface conjugation with oleic acid have been reported by many research groups. For example, Marinca et al. introduced a new synthetic route to prepare oleic acid-coated magnetite NPs. In the first step, iron and hematite were mixed and then heated. In the second step, the resulting magnetite powder and oleic acid are wet-mechanically milled. In their study, they did a comparison between the dry milling and wet milling NPs. Based on their experiment they concluded that the magnetite particles obtained by wet milling have a higher magnetization [198]. Velusamy et al. found that the conjugation of oleic acid onto the surface of IONPs can significantly reduce the growth and metabolism of biofilms and thus it can be used to inhibit the biofilm formation onto the surface of biomaterials [199].

However, in a biomedical scenario, the use of lipophilic substances coated IONPs is a not a good choice and thus the practical use of these NPs is greatly limited. To enhance the practical applications of IONPs, the research is focusing on synthesizing hydrophilic or water-soluble IONPs. Different organic molecules such as amino acids [200], citric acid [201], vitamins [202,203], cyclodextrin [204], dopamine [205,206], lauric acid [207], dimercaptosuccinic acid (DMSA) [208,209] are often used to modify the surface of IONPs by adopting different synthesis approaches so that the water solubility of IONPs can be greatly enhanced. One approach is to add these small organic molecules directly during the synthesis procedure. Jin et al. modified $\mathrm{Fe}_{3} \mathrm{O}_{4}$ NPs with arginine, lysine and poly-L-lysine, respectively. They found that these samples have high bacterial capture efficiency in the $\mathrm{pH}$ range 4-10 [200]. Recently, Karimzadeh et al. developed a novel method for the synthesis of amino acid modified $\mathrm{Fe}_{3} \mathrm{O}_{4}$ NPs based on CED [210]. Sahoo et al. have described that citric acid can adsorb on the surface of magnetite NPs through the coordination of one or two carboxylate functional groups [211]. Durdureanu-Angheluta et al. adopted the liquid laser ablation technique to synthesize citric acid-coated IONPs having spherical nature with an average size of about $60 \mathrm{~nm}$. Their synthesized NPs have a core-shell structure and contain an outer layer of hydrophilic material of citric acid, which helps the NPs to stabilize in aqueous dispersions [212]. On the other hand, a cheap hydrophilic substance with lipophilic cavities, known as $\beta$-cyclodextrin is also used in the surface decoration of IONPs. In what follows, Li et al. prepared $\beta$-cyclodextrin modified $\mathrm{Fe}_{3} \mathrm{O}_{4} \mathrm{NPs}$ by $\mathrm{N}_{2}$ plasma-induced grafting. This composite is suitable for the removal of organic and inorganic contaminants [204]. A few research groups also used the ascorbic acid (vitamin C) owing to their water solubility and anti-oxidant property, for surface modification of IONPs and concluded that these surface decorated NPs can be used as MRI contrast agents [203]. 
The hydrophobic nature of the IONPs can be changed to hydrophilic by adopting three different approaches, for example, amphiphilic polymer coatings [197], ligand exchange [213] and surface fatty acid oxidation [214]. Among them, ligand exchange involves an excess of ligand molecules, and the hydrophobic groups on the surface of the NPs are displaced by the ligand exchange reaction. Patil et al. further functionalized the oleic acid-coated $\mathrm{Fe}_{3} \mathrm{O}_{4} \mathrm{NPs}$ with betaine- $\mathrm{HCl}(\mathrm{BTH})$ to create a new hydrophilic shell that ultimately resulted in the transfer from non-aqueous phase to aqueous phase. IONPs can also be transferred to aqueous solutions by oxidizing the oleic acid layer on the surface of NPs [215]. Cai et al. proposed a universal and efficient method for the large-scale transfer of hydrophobic $\mathrm{Fe}_{3} \mathrm{O}_{4}$ NPs to the aqueous phase [216]. This method is based on the oxidative decomposition of oleic acid in a reverse micelle system assisted by poly(vinylpyrrolidone) (PVP) [217]. The phase transfer process is as follows. Firstly, the prepared hydrophobic $\mathrm{Fe}_{3} \mathrm{O}_{4} \mathrm{NPs}$ were dispersed in cyclohexane, and then tert-butanol, $\mathrm{K}_{2} \mathrm{CO}_{3}$, aqueous PVP solution and oxidizing agent were added and stirred at room temperature for $2 \mathrm{~h}$. Finally, the NPs obtained were washed with ethanol and water for three times. The resulting NPs have superior features, like ideal colloidal stability, excellent biocompatibility, low cytotoxicity. Moreover, this phase transfer strategy also applies to other oleic acid-coated NPs [216].

\section{Conclusions}

This review summarizes the surface modification of IONPs by different organic molecules including surfactants as well as polymers and inorganic materials that include silicon groups, carbon, metal [218] and metal oxides/sulfides. Surface coating can improve the stability, biocompatibility, and even the solubility of IONPs, which greatly expands the scope of application of IONPs. Different synthesis methods, reaction mechanisms, performance, improvement and potential applications were also discussed. Important research findings in recent years are cited in this review, in the hope that this provides the readers a necessary background with logically coherent arguments about the surface modification of IONPs.

At present, although some progress has been made in the research on the modification of IONPs, several limitations still exist. Firstly, it is still a challenge to absolutely control the shape and size distribution of magnetic IONPs. Secondly, the issue of how to maintain the long-term stability of functionalized IONPs also needs to be addressed [50] Finally, most of the applications, especially those related to the clinical aspects, still remain in the theoretical stage and there is a long way to go before they can be applied in practice. Thus, much effort needs to be devoted to optimizing synthetic routes to obtain better IONPs. At the same time, it is essential to develop accessible, efficient, stable and environmentally friendly surface modification materials. Future research will focus on the multifunctional MNPs needed in clinical practice [57] In the future, with the improvement of surface modification technology and the development of surface modification materials, more and more multifunctional NPs will be developed and put into practical application.

Author Contributions: H.J. provided the direction of the review; N.Z. wrote the original draft and M.U.F., M.W.A., I.O.U. reviewed it. P.Y. and J.N. provided some articles and studying materials. H.L. and X.N. gave some guidance in writing a review.

Funding: This work was supported by the National Natural Science Foundation of China 51302030, 51272038, 61474015, 61474014, and the National Program on Key Basic Research Project (973 Program) 2013CB933301, 2018YFA0306100.

Conflicts of Interest: The authors declare no conflict of interest.

\section{References}

1. Rossi, L.M.; Costa, N.J.S.; Silva, F.P.; Wojcieszak, R. Magnetic nanomaterials in catalysis: Advanced catalysts for magnetic separation and beyond. Green Chem. 2014, 16, 2906-2933. [CrossRef]

2. Zhang, H.W.; Liu, Y.; Sun, S.H. Synthesis and assembly of magnetic nanoparticles for information and energy storage applications. Front. Phys. Chin. 2010, 5, 347-356. [CrossRef] 
3. Tang, S.C.N.; Lo, I.M.C. Magnetic nanoparticles: Essential factors for sustainable environmental applications. Water Res. 2013, 47, 2613-2632. [CrossRef] [PubMed]

4. Laurent, S.; Dutz, S.; Hafeli, U.O.; Mahmoudi, M. Magnetic fluid hyperthermia: Focus on superparamagnetic iron oxide nanoparticles. Adv. Colloid Interface 2011, 166, 8-23. [CrossRef] [PubMed]

5. Li, X.-B.; Gao, Y.-J.; Wang, Y.; Zhan, F.; Zhang, X.-Y.; Kong, Q.-Y.; Zhao, N.-J.; Guo, Q.; Wu, H.-L.; Li, Z.-J.; et al. Self-Assembled Framework Enhances Electronic Communication of Ultrasmall-Sized Nanoparticles for Exceptional Solar Hydrogen Evolution. J. Am. Chem. Soc. 2017, 139, 4789-4796. [CrossRef] [PubMed]

6. Reddy, L.H.; Arias, J.L.; Nicolas, J.; Couvreur, P. Magnetic Nanoparticles: Design and Characterization, Toxicity and Biocompatibility, Pharmaceutical and Biomedical Applications. Chem. Rev. 2012, 112, 5818-5878. [CrossRef] [PubMed]

7. Liu, G.; Gao, J.H.; Ai, H.; Chen, X.Y. Applications and Potential Toxicity of Magnetic Iron Oxide Nanoparticles. Small 2013, 9, 1533-1545. [CrossRef] [PubMed]

8. Bae, K.H.; Park, M.; Do, M.J.; Lee, N.; Ryu, J.H.; Kim, G.W.; Kim, C.; Park, T.G.; Hyeon, T. Chitosan Oligosaccharide-Stabilized Ferrimagnetic Iron Oxide Nanocubes for Magnetically Modulated Cancer Hyperthermia. ACS Nano 2012, 6, 5266-5273. [CrossRef] [PubMed]

9. Blanco-Andujar, C.; Walter, A.; Cotin, G.; Bordeianu, C.; Mertz, D.; Felder-Flesch, D.; Begin-Colin, S. Design of iron oxide-based nanoparticles for MRI and magnetic hyperthermia. Nanomedicine 2016, 11, 1889-1910. [CrossRef] [PubMed]

10. Gruttner, C.; Muller, K.; Teller, J.; Westphal, F. Synthesis and functionalisation of magnetic nanoparticles for hyperthermia applications. Int. J. Hyperther. 2013, 29, 777-789. [CrossRef] [PubMed]

11. Estelrich, J.; Escribano, E.; Queralt, J.; Antonia Busquets, M. Iron Oxide Nanoparticles for Magnetically-Guided and Magnetically-Responsive Drug Delivery. Int. J. Mol. Sci. 2015, 16, 8070-8101. [CrossRef] [PubMed]

12. Ding, Y.; Shen, S.Z.; Sun, H.; Sun, K.; Liu, F.; Qi, Y.; Yan, J. Design and construction of polymerized-chitosan coated $\mathrm{Fe}_{3} \mathrm{O}_{4}$ magnetic nanoparticles and its application for hydrophobic drug delivery. Mater. Sci. Eng. C Mater. Biol. Appl. 2015, 48, 487-498. [CrossRef] [PubMed]

13. Wahajuddin, S.A. Superparamagnetic iron oxide nanoparticles: Magnetic nanoplatforms as drug carriers. Int. J. Nanomed. 2012, 7, 3445-3471. [CrossRef] [PubMed]

14. Lee, N.; Yoo, D.; Ling, D.; Cho, M.H.; Hyeon, T.; Cheon, J. Iron Oxide Based Nanoparticles for Multimodal Imaging and Magnetoresponsive Therapy. Chem. Rev. 2015, 115, 10637-10689. [CrossRef] [PubMed]

15. Lee, N.; Hyeon, T. Designed synthesis of uniformly sized iron oxide nanoparticles for efficient magnetic resonance imaging contrast agents. Chem. Soc. Rev. 2012, 41, 2575-2589. [CrossRef] [PubMed]

16. Kim, B.H.; Lee, N.; Kim, H.; An, K.; Park, Y.I.; Choi, Y.; Shin, K.; Lee, Y.; Kwon, S.G.; Na, H.B.; et al. Large-Scale Synthesis of Uniform and Extremely Small-Sized Iron Oxide Nanoparticles for High-Resolution T-1 Magnetic Resonance Imaging Contrast Agents. J. Am. Chem. Soc. 2011, 133, 12624-12631. [CrossRef] [PubMed]

17. Fatima, H.; Kim, K.S. Magnetic nanoparticles for bioseparation. Korean J. Chem. Eng. 2017, 34, 589-599. [CrossRef]

18. Kannan, K.; Mukherjee, J.; Gupta, M.N. Use of Polyethyleneimine Coated $\mathrm{Fe}_{3} \mathrm{O}_{4}$ Nanoparticles as an Ion-Exchanger for Protein Separation. Sci. Adv. Mater. 2013, 5, 1477-1484. [CrossRef]

19. Zhang, G.X.; Qie, F.X.; Hou, J.X.; Luo, S.Z.; Luo, L.; Sun, X.M.; Tan, T.W. One-pot solvothermal method to prepare functionalized $\mathrm{Fe}_{3} \mathrm{O}_{4}$ nanoparticles for bioseparation. J. Mater. Res. 2012, 2, 1006-1013. [CrossRef]

20. Jiang, S.; Eltoukhy, A.A.; Love, K.T.; Langer, R.; Anderson, D.G. Lipidoid-Coated Iron Oxide Nanoparticles for Efficient DNA and siRNA delivery. Nano Lett. 2012, 13, 1059-1064. [CrossRef] [PubMed]

21. Kami, D.; Takeda, S.; Itakura, Y.; Gojo, S.; Watanabe, M.; Toyoda, M. Application of Magnetic Nanoparticles to Gene Delivery. Int. J. Mol. Sci. 2011, 12, 3705-3722. [CrossRef] [PubMed]

22. Mykhaylyk, O.; Sobisch, T.; Almstatter, I.; Sanchez-Antequera, Y.; Brandt, S.; Anton, M.; Doblinger, M.; Eberbeck, D.; Settles, M.; Braren, R.; et al. Silica-Iron Oxide Magnetic Nanoparticles Modified for Gene Delivery: A Search for Optimum and Quantitative Criteria. Pharm. Res. 2012, 29, 1344-1365. [CrossRef] [PubMed]

23. Martin, M.; Salazar, P.; Villalonga, R.; Campuzano, S.; Pingarron, J.M.; Gonzalez-Mora, J.L. Preparation of core-shell $\mathrm{Fe}_{3} \mathrm{O}_{4} @$ poly(dopamine) magnetic nanoparticles for biosensor construction. J. Mater. Chem. B 2014, 2, 739-746. [CrossRef] 
24. Shi, X.H.; Gu, W.; Li, B.Y.; Chen, N.N.; Zhao, K.; Xian, Y.Z. Enzymatic biosensors based on the use of metal oxide nanoparticles. Microchim. Acta 2014, 181, 1-22. [CrossRef]

25. Baghayeri, M.; Zare, E.N.; Lakouraj, M.M. A simple hydrogen peroxide biosensor based on a novel electro-magnetic poly(p-phenylenediamine)@ $\mathrm{Fe}_{3} \mathrm{O}_{4}$ nanocomposite. Biosens. Bioelectron. 2014, 55, 259-265. [CrossRef] [PubMed]

26. Cao, M.; Li, Z.H.; Wang, J.L.; Ge, W.P.; Yue, T.L.; Li, R.H.; Colvin, V.L.; Yu, W.W. Food related applications of magnetic iron oxide nanoparticles: Enzyme immobilization, protein purification, and food analysis. Trends Food Sci. Tech. 2012, 27, 47-56. [CrossRef]

27. Okoli, C.; Boutonnet, M.; Mariey, L.; Jaras, S.; Rajarao, G. Application of magnetic iron oxide nanoparticles prepared from microemulsions for protein purification. J. Chem. Technol. Biotechnol. 2011, 86, 1386-1393. [CrossRef]

28. Okoli, C.; Fornara, A.; Qin, J.; Toprak, M.S.; Dalhammar, G.; Muhammed, M.; Rajarao, G.K. Characterization of Superparamagnetic Iron Oxide Nanoparticles and Its Application in Protein Purification. J. Nanosci. Nanotechnol. 2011, 11, 10201-10206. [CrossRef] [PubMed]

29. Peterson, R.D.; Chen, W.L.; Cunningham, B.T.; Andrade, J.E. Enhanced sandwich immunoassay using antibody-functionalized magnetic iron-oxide nanoparticles for extraction and detection of soluble transferrin receptor on a photonic crystal biosensor. Biosens. Bioelectron. 2015, 74, 815-822. [CrossRef] [PubMed]

30. Nor, N.M.; Razak, K.A.; Tan, S.C.; Noordin, R. Properties of surface functionalized iron oxide nanoparticles (ferrofluid) conjugated antibody for lateral flow immunoassay application. J. Alloys Compd. 2012, 538, 100-106.

31. Yang, M.Z.; Guan, Y.P.; Yang, Y.; Xia, T.T.; Xiong, W.B.; Guo, C. A sensitive and rapid immunoassay for mycoplasma pneumonia based on $\mathrm{Fe}_{3} \mathrm{O}_{4}$ nanoparticles. Mater. Lett. 2014, 137, 113-116. [CrossRef]

32. Li, L.; Jiang, W.; Luo, K.; Song, H.; Lan, F.; Wu, Y.; Gu, Z. Superparamagnetic Iron Oxide Nanoparticles as MRI contrast agents for Non-invasive Stem Cell Labeling and Tracking. Theranostics 2013, 3, 595-615. [CrossRef] [PubMed]

33. Wang, X.Q.; Wei, F.; Liu, A.J.; Wang, L.; Wang, J.C.; Ren, L.; Liu, W.M.; Tu, Q.; Li, L.; Wang, J.Y. Cancer stem cell labeling using poly(L-lysine)-modified iron oxide nanoparticles. Biomaterials 2012, 33, 3719-3732. [CrossRef] [PubMed]

34. Soenen, S.J.H.; Himmelreich, U.; Nuytten, N.; De Cuyper, M. Cytotoxic effects of iron oxide nanoparticles and implications for safety in cell labelling. Biomaterials 2011, 32, 195-205. [CrossRef] [PubMed]

35. Mohammadi, A.; Barikani, M.; Barmar, M. Effect of surface modification of $\mathrm{Fe}_{3} \mathrm{O}_{4}$ nanoparticles on thermal and mechanical properties of magnetic polyurethane elastomer nanocomposites. J. Mater. Sci. 2013, 48, 7493-7502. [CrossRef]

36. Sun, S.N.; Wei, C.; Zhu, Z.Z.; Hou, Y.L.; Venkatraman, S.S.; Xu, Z.C. Magnetic iron oxide nanoparticles: Synthesis and surface coating techniques for biomedical applications. Chin. Phys. B 2014, 23. [CrossRef]

37. Mahmoudi, M.; Sant, S.; Wang, B.; Laurent, S.; Sen, T. Superparamagnetic iron oxide nanoparticles (SPIONs): Development, surface modification and applications in chemotherapy. Adv. Drug Deliv. Rev. 2011, 63, $24-46$. [CrossRef] [PubMed]

38. Laurent, S.; Forge, D.; Port, M.; Roch, A.; Robic, C.; Elst, L.V.; Muller, R.N. Magnetic iron oxide nanoparticles: Synthesis, stabilization, vectorization, physicochemical characterizations, and biological applications. Chem. Rev. 2008, 108, 2064-2110. [CrossRef] [PubMed]

39. Petcharoen, K.; Sirivat, A. Synthesis and characterization of magnetite nanoparticles via the chemical co-precipitation method. Mater. Sci. Eng. B-Adv. 2012, 177, 421-427. [CrossRef]

40. Li, H.; Lu, Z.; Cheng, G.; Rong, K.F.; Chen, F.X.; Chen, R. HEPES-involved hydrothermal synthesis of $\mathrm{Fe}_{3} \mathrm{O}_{4}$ nanoparticles and their biological application. RSC Adv. 2015, 5, 5059-5067. [CrossRef]

41. Sharma, G.; Jeevanandam, P. Synthesis of self-assembled prismatic iron oxide nanoparticles by a novel thermal decomposition route. RSC Adv. 2013, 3, 189-200. [CrossRef]

42. Okoli, C.; Sanchez-Dominguez, M.; Boutonnet, M.; Jaras, S.; Civera, C.; Solans, C.; Kuttuva, G.R. Comparison and Functionalization Study of Microemulsion-Prepared Magnetic Iron Oxide Nanoparticles. Langmuir 2012, 28, 8479-8485. [CrossRef] [PubMed] 
43. Karimzadeh, I.; Aghazadeh, M.; Doroudi, T.; Ganjali, M.R.; Kolivand, P.H. Effective Preparation, Characterization and In Situ Surface Coating of Superparamagnetic $\mathrm{Fe}_{3} \mathrm{O}_{4}$ Nanoparticles with Polyethyleneimine Through Cathodic Electrochemical Deposition (CED). Curr. Nanosci. 2017, 13, 167-174. [CrossRef]

44. Morjan, I.; Alexandrescu, R.; Dumitrache, F.; Birjega, R.; Fleaca, C.; Soare, I.; Luculescu, C.R.; Filoti, G.; Kuncer, V.; Vekas, L.; et al. Iron Oxide-Based Nanoparticles with Different Mean Sizes Obtained by the Laser Pyrolysis: Structural and Magnetic Properties. J. Nanosci. Nanotechnol. 2010, 10, 1223-1234. [CrossRef] [PubMed]

45. Ooi, F.; DuChene, J.S.; Qiu, J.J.; Graham, J.O.; Engelhard, M.H.; Cao, G.X.; Gai, Z.; Wei, W.D. A Facile Solvothermal Synthesis of Octahedral $\mathrm{Fe}_{3} \mathrm{O}_{4}$ Nanoparticles. Small 2015, 11, 2649-2653. [CrossRef] [PubMed]

46. Abbas, M.; Takahashi, M.; Kim, C. Facile sonochemical synthesis of high-moment magnetite $\left(\mathrm{Fe}_{3} \mathrm{O}_{4}\right)$ nanocube. J. Nanopart. Res. 2013, 15, 1354. [CrossRef]

47. Wang, J.H.; Gao, M.X.; Wang, D.S.; Li, X.; Dou, Y.B.; Liu, Y.F.; Pan, H.G. Chemical vapor deposition prepared bi-morphological carbon-coated $\mathrm{Fe}_{3} \mathrm{O}_{4}$ composites as anode materials for lithium-ion batteries. J. Power Sources 2015, 282, 257-264. [CrossRef]

48. Solano, E.; Perez-Mirabet, L.; Martinez-Julian, F.; Guzman, R.; Arbiol, J.; Puig, T.; Obradors, X.; Yanez, R.; Pomar, A.; Ricart, S.; et al. Facile and efficient one-pot solvothermal and microwave-assisted synthesis of stable colloidal solutions of $\mathrm{MFe}_{2} \mathrm{O}_{4}$ spinel magnetic nanoparticles. J. Nanopart. Res. 2012, 14, 15. [CrossRef]

49. Strobel, R.; Pratsinis, S.E. Flame aerosol synthesis of smart nanostructured materials. J. Mater. Chem. 2007, 17, 4743-4756. [CrossRef]

50. Wu, W.; Wu, Z.; Yu, T.; Jiang, C.; Kim, W.-S. Recent progress on magnetic iron oxide nanoparticles: Synthesis, surface functional strategies and biomedical applications. Sci. Technol. Adv. Mater. 2015, 16, 023501. [CrossRef] [PubMed]

51. Maleki, A. $\mathrm{Fe}_{3} \mathrm{O}_{4} / \mathrm{SiO}_{2}$ nanoparticles: An efficient and magnetically recoverable nanocatalyst for the one-pot multicomponent synthesis of diazepines. Tetrahedron 2012, 68, 7827-7833. [CrossRef]

52. Kiasat, A.R.; Davarpanah, J. $\mathrm{Fe}_{3} \mathrm{O}_{4} @$ silica sulfuric acid nanoparticles: An efficient reusable nanomagnetic catalyst as potent solid acid for one-pot solvent-free synthesis of indazolo 2,1-b phthalazine-triones and pyrazolo 1,2-b phthalazine-diones. J. Mol. Catal. A-Chem. 2013, 373, 46-54. [CrossRef]

53. Sun, H.; Zeng, X.; Liu, M.; Elingarami, S.; Li, G.; Shen, B.; He, N. Synthesis of Size-Controlled $\mathrm{Fe}_{3} \mathrm{O}_{4} @ \mathrm{SiO}_{2}$ Magnetic Nanoparticles for Nucleic Acid Analysis. J. Nanosci. Nanotechnol. 2012, 12, 267-273. [CrossRef] [PubMed]

54. Sun, W.X.; Sun, W.Z.; Kessler, M.R.; Bowler, N.; Dennis, K.W.; McCallum, R.W.; Li, Q.; Tan, X.L. Multifunctional Properties of Cyanate Ester Composites with $\mathrm{SiO}_{2}$ Coated $\mathrm{Fe}_{3} \mathrm{O}_{4}$ Fillers. ACS Appl. Mater. Int. 2013, 5, 1636-1642. [CrossRef] [PubMed]

55. Li, C.Y.; Ma, C.; Wang, F.; Xi, Z.J.; Wang, Z.F.; Deng, Y.; He, N.Y. Preparation and Biomedical Applications of Core-Shell Silica/Magnetic Nanoparticle Composites. J. Nanosci. Nanotechnol. 2012, 12, 2964-2972. [CrossRef] [PubMed]

56. Abbas, M.; Rao, B.P.; Islam, M.N.; Naga, S.M.; Takahashi, M.; Kim, C. Highly stable-silica encapsulating magnetite nanoparticles $\left(\mathrm{Fe}_{3} \mathrm{O}_{4} / \mathrm{SiO}_{2}\right)$ synthesized using single surfactantless-polyol process. Ceram. Int. 2014, 40, 1379-1385. [CrossRef]

57. Chu, X.; Yu, J.; Hou, Y.-L. Surface modification of magnetic nanoparticles in biomedicine. Chinese. Phys. B. 2015, 24, 014704. [CrossRef]

58. Hui, C.; Shen, C.M.; Tian, J.F.; Bao, L.H.; Ding, H.; Li, C.; Tian, Y.A.; Shi, X.Z.; Gao, H.J. Core-shell $\mathrm{Fe}_{3} \mathrm{O}_{4} @ \mathrm{SiO}_{2}$ nanoparticles synthesized with well-dispersed hydrophilic $\mathrm{Fe}_{3} \mathrm{O}_{4}$ seeds. Nanoscale 2011, 3, 701-705. [CrossRef] [PubMed]

59. Zhao, L.; Yu, J.G.; Chang, B.; Zhao, X.J. Preparation and formation mechanism of monodispersed silicon dioxide spherical particles. Acta Chim. Sin. 2003, 61, 562-566.

60. Malvindi, M.A.; De Matteis, V.; Galeone, A.; Brunetti, V.; Anyfantis, G.C.; Athanassiou, A.; Cingolani, R.; Pompa, P.P. Toxicity assessment of silica coated iron oxide nanoparticles and biocompatibility improvement by surface engineering. PLoS ONE 2014, 9, e85835. [CrossRef] [PubMed]

61. Uribe Madrid, S.I.; Pal, U.; Kang, Y.S.; Kim, J.; Kwon, H.; Kim, J. Fabrication of $\mathrm{Fe}_{3} \mathrm{O}_{4} @ \mathrm{mSiO}_{2}$ Core-Shell Composite Nanoparticles for Drug Delivery Applications. Nanoscale Res. Lett. 2015, 10, 217. [CrossRef] [PubMed] 
62. Sonmez, M.; Georgescu, M.; Alexandrescu, L.; Gurau, D.; Ficai, A.; Ficai, D.; Andronescu, E. Synthesis and applications of $\mathrm{Fe}_{3} \mathrm{O}_{4} / \mathrm{SiO}_{2}$ core-shell materials. Curr. Pharm. Des. 2015, 21, 5324-5335. [CrossRef] [PubMed]

63. Du, Y.; Li, L.; Leung, C.W.; Lai, P.T.; Pong, P.W.T. Synthesis and Characterization of Silica-Encapsulated Iron Oxide Nanoparticles. IEEE Trans. Magn. 2014, 50, 1-4. [CrossRef]

64. Yang, J.; Shen, D.; Wei, Y.; Li, W.; Zhang, F.; Kong, B.; Zhang, S.; Teng, W.; Fan, J.; Zhang, W.; et al. Monodisperse core-shell structured magnetic mesoporous aluminosilicate nanospheres with large dendritic mesochannels. Nano Res. 2015, 8, 2503-2514. [CrossRef]

65. Ding, H.L.; Zhang, Y.X.; Wang, S.; Xu, J.M.; Xu, S.C.; Li, G.H. Fe $\mathrm{O}_{4} @ \mathrm{SiO}_{2}$ Core/Shell Nanoparticles: The Silica Coating Regulations with a Single Core for Different Core Sizes and Shell Thicknesses. Chem. Mater. 2012, 24, 4572-4580. [CrossRef]

66. Lu, C.Y.; Puig, T.; Obradors, X.; Ricart, S.; Ros, J. Ultra-fast microwave-assisted reverse microemulsion synthesis of $\mathrm{Fe}_{3} \mathrm{O}_{4} @ \mathrm{SiO}_{2}$ core-shell nanoparticles as a highly recyclable silver nanoparticle catalytic platform in the reduction of 4-nitroaniline. RSC Adv. 2016, 6, 88762-88769. [CrossRef]

67. Li, Y.; Hu, Y.; Jiang, H.; Li, C. Double-faced $\gamma-\mathrm{Fe}_{2} \mathrm{O}_{3}|| \mathrm{SiO}_{2}$ nanohybrids: Flame synthesis, in situ selective modification and highly interfacial activity. Nanoscale 2013, 5, 5360. [CrossRef] [PubMed]

68. Tricoli, A.; Righettoni, M.; Krumeich, F.; Stark, W.J.; Pratsinis, S.E. Scalable flame synthesis of $\mathrm{SiO}_{2}$ nanowires: Dynamics of growth. Nanotechnology 2010, 21, 7. [CrossRef] [PubMed]

69. Tani, T.; Madler, L.; Pratsinis, S.E. Homogeneous ZnO nanoparticles by flame spray pyrolysis. J. Nanopart. Res. 2002, 4, 337-343. [CrossRef]

70. Jokanovic, V.; Spasic, A.M.; Uskokovic, D. Designing of nanostructured hollow $\mathrm{TiO}_{2}$ spheres obtained by ultrasonic spray pyrolysis. J. Colloid Interfaces Sci. 2004, 278, 342-352. [CrossRef] [PubMed]

71. Strobel, R.; Pratsinis, S.E. Direct synthesis of maghemite, magnetite and wustite nanoparticles by flame spray pyrolysis. Adv. Powder Technol. 2009, 20, 190-194. [CrossRef]

72. Kelesidis, G.A.; Furrer, F.M.; Wegner, K.; Pratsinis, S.E. Impact of Humidity on Silica Nanoparticle Agglomerate Morphology and Size Distribution. Langmuir 2018, 34, 8532-8541. [CrossRef] [PubMed]

73. Teleki, A.; Suter, M.; Kidambi, P.; Ergeneman, O.; Krumeich, F.; Nelson, B.; Pratsinis, S. Hermetically Coated Superparamagnetic $\mathrm{Fe}_{2} \mathrm{O}_{3}$ Particles with $\mathrm{SiO}_{2}$ Nanofilms. Chem. Mater. 2009, 21, 2094-2100. [CrossRef]

74. Setyawan, H.; Fajaroh, F.; Widiyastuti, W.; Winardi, S.; Lenggoro, I.W.; Mufti, N. One-step synthesis of silica-coated magnetite nanoparticles by electrooxidation of iron in sodium silicate solution. J. Nanopart. Res. 2012, 14, 807. [CrossRef]

75. Roto, R.; Yusran, Y.; Kuncaka, A. Magnetic adsorbent of $\mathrm{Fe}_{3} \mathrm{O}_{4} @ \mathrm{SiO}_{2}$ core-shell nanoparticles modified with thiol group for chloroauric ion adsorption. Appl. Surf. Sci. 2016, 377, 30-36. [CrossRef]

76. Fajaroh, F.; Setyawan, H.; Widiyastuti, W.; Winardi, S. Synthesis of magnetite nanoparticles by surfactant-free electrochemical method in an aqueous system. Adv. Powder Technol. 2012, 23, 328-333. [CrossRef]

77. Fajaroh, F.; Sumari, N. Effect of concentration of sodium silicate solution in the synthesis of silica-coated magnetite nanoparticles by ultrasonication. In Proceedings of the 6th Nanoscience and Nanotechnology Symposium, Surakarta, Indonesia, 4-5 November 2015; American Institute of Physics: Melville, NY, USA, 2016.

78. Laurent, S.; Forge, D.; Port, M.; Roch, A.; Robic, C.; Elst, L.V.; Muller, R.N. Magnetic Iron Oxide Nanoparticles: Synthesis, Stabilization, Vectorization, Physicochemical Characterizations, and Biological Applications. Chem. Rev. 2010, 110, 2574. [CrossRef]

79. Yang, H.; Zhuang, Y.M.; Sun, Y.; Dai, A.T.; Shi, X.Y.; Wu, D.M.; Li, F.Y.; Hu, H.; Yang, S.P. Targeted dual-contrast T-1- and T-2-weighted magnetic resonance imaging of tumors using multifunctional gadolinium-labeled superparamagnetic iron oxide nanoparticles. Biomaterials 2011, 32, 4584-4593. [CrossRef] [PubMed]

80. Wang, F.; Pauletti, G.M.; Wang, J.T.; Zhang, J.M.; Ewing, R.C.; Wang, Y.L.; Shi, D.L. Dual SurfaceFunctionalized Janus Nanocomposites of Polystyrene $/ \mathrm{Fe}_{3} \mathrm{O}_{4} @ \mathrm{SiO}_{2}$ for Simultaneous Tumor Cell Targeting and Stimulus-Induced Drug Release. Adv. Mater. 2013, 25, 3485-3489. [CrossRef] [PubMed]

81. Wang, J.H.; Zheng, S.R.; Shao, Y.; Liu, J.L.; Xu, Z.Y.; Zhu, D.Q. Amino-functionalized $\mathrm{Fe}_{3} \mathrm{O}_{4} @ \mathrm{SiO}_{2}$ core-shell magnetic nanomaterial as a novel adsorbent for aqueous heavy metals removal. J. Colloid Interfaces Sci. 2010, 349, 293-299. [CrossRef] [PubMed] 
82. Zhang, X.L.; He, M.L.; Liu, J.H.; Liao, R.; Zhao, L.Q.; Xie, J.R.; Wang, R.J.; Yang, S.T.; Wang, H.F.; Liu, Y.F. $\mathrm{Fe}_{3} \mathrm{O}_{4} @ \mathrm{C}$ nanoparticles as high-performance Fenton-like catalyst for dye decoloration. Chin. Sci. Bull. 2014, 59, 3406-3412. [CrossRef]

83. Lim, Y.S.; Lai, C.W.; Hamid, S.B.A. Porous 3D carbon decorated $\mathrm{Fe}_{3} \mathrm{O}_{4}$ nanocomposite electrode for highly symmetrical supercapacitor performance. RSC Adv. 2017, 7, 23030-23040. [CrossRef]

84. Wang, J.C.; Zhou, H.; Zhuang, J.D.; Liu, Q. Magnetic gamma- $\mathrm{Fe}_{2} \mathrm{O}_{3}, \mathrm{Fe}_{3} \mathrm{O}_{4}$, and Fe nanoparticles confined within ordered mesoporous carbons as efficient microwave absorbers. Phys. Chem. Chem. Phys. 2015, 17, 3802-3812. [CrossRef] [PubMed]

85. He, C.N.; Wu, S.; Zhao, N.Q.; Shi, C.S.; Liu, E.Z.; Li, J.J. Carbon-Encapsulated $\mathrm{Fe}_{3} \mathrm{O}_{4}$ Nanoparticles as a High-Rate Lithium Ion Battery Anode Material. ACS Nano. 2013, 7, 4459-4469. [CrossRef] [PubMed]

86. Du, Y.C.; Liu, W.W.; Qiang, R.; Wang, Y.; Han, X.J.; Ma, J.; Xu, P. Shell Thickness-Dependent Microwave Absorption of Core-Shell $\mathrm{Fe}_{3} \mathrm{O}_{4} @ \mathrm{C}$ Composites. ACS Appl. Mater. Int. 2014, 6, 12997-13006. [CrossRef] [PubMed]

87. Liu, J.; Zhou, Y.C.; Liu, F.; Liu, C.P.; Wang, J.B.; Pan, Y.; Xue, D.F. One-pot synthesis of mesoporous interconnected carbon-encapsulated $\mathrm{Fe}_{3} \mathrm{O}_{4}$ nanospheres as superior anodes for Li-ion batteries. RSC Adv. 2012, 2, 2262-2265. [CrossRef]

88. Liu, J.; Liu, S.Q.; Zhuang, S.X.; Wang, X.W.; Tu, F.Y. Synthesis of carbon-coated $\mathrm{Fe}_{3} \mathrm{O}_{4}$ nanorods as electrode material for supercapacitor. Ionics 2013, 19, 1255-1261. [CrossRef]

89. Sinan, N.; Unur, $\mathrm{E}$. $\mathrm{Fe}_{3} \mathrm{O}_{4}$ / carbon nanocomposite: Investigation of capacitive \& magnetic properties for supercapacitor applications. Mater. Chem. Phys. 2016, 183, 571-579.

90. Wang, Y.H.; He, P.; Zhao, X.M.; Lei, W.; Dong, F.Q. Coal tar residues-based nanostructured activated carbon $/ \mathrm{Fe}_{3} \mathrm{O}_{4}$ composite electrode materials for supercapacitors. J. Solid State Electr. 2014, 18, 665-672. [CrossRef]

91. Guo, C.; Wang, L.L.; Zhu, Y.C.; Wang, D.F.; Yang, Q.Q.; Qian, Y.T. $\mathrm{Fe}_{3} \mathrm{O}_{4}$ nanoflakes in an N-doped carbon matrix as high-performance anodes for lithium ion batteries. Nanoscale 2015, 7, 10123-10129. [CrossRef] [PubMed]

92. Liang, J.; Xiao, C.H.; Chen, X.; Gao, R.X.; Ding, S.J. Porous gamma-Fe $\mathrm{O}_{3}$ spheres coated with N-doped carbon from polydopamine as Li-ion battery anode materials. Nanotechnology 2016, 27, 215403. [CrossRef] [PubMed]

93. Yang, T.T.; Zhu, W.K.; Liu, W.L.; Kong, F.G.; Ren, M.M.; Liu, Q.Z.; Yang, Z.Z.; Wang, X.Q.; Duan, X.L. Preparation of yolk-shell $\mathrm{Fe}_{3} \mathrm{O}_{4} @ \mathrm{~N}$-doped carbon nanocomposite particles as anode in lithium ion batteries. J. Mater. Sci. 2017, 28, 11569-11575. [CrossRef]

94. Yang, L.; Guo, G.N.; Sun, H.J.; Shen, X.D.; Hu, J.H.; Dong, A.G.; Yang, D. Ionic Liquid as the C and N Sources to Prepare Yolk-shell $\mathrm{Fe}_{3} \mathrm{O}_{4} @ \mathrm{~N}$-doped Carbon Nanoparticles and its High Performance in Lithium-ion Battery. Electrochim. Acta 2016, 190, 797-803. [CrossRef]

95. Hadidi, L.; Davari, E.; Ivey, D.G.; Veinot, J.G.C. Microwave-assisted synthesis and prototype oxygen reduction electrocatalyst application of $\mathrm{N}$-doped carbon-coated $\mathrm{Fe}_{3} \mathrm{O}_{4}$ nanorods. Nanotechnology 2017, 28, 095707. [CrossRef] [PubMed]

96. Wang, W.; $\mathrm{Si}$, J.J.; Li, J.; Wang, Q.; Chen, S.L. Hybrid of $\mathrm{Fe}_{3} \mathrm{O}_{4}$ nanorods and N-doped carbon as efficient oxygen reduction electrocatalyst. Int. J. Hydrog. Energy 2016, 41, 16858-16864. [CrossRef]

97. Guan, D.H.; Gao, Z.; Yang, W.L.; Wang, J.; Yuan, Y.; Wang, B.; Zhang, M.L.; Liu, L.H. Hydrothermal synthesis of carbon nanotube/cubic $\mathrm{Fe}_{3} \mathrm{O}_{4}$ nanocomposite for enhanced performance supercapacitor electrode material. Mat. Sci. Eng. B 2013, 178, 736-743. [CrossRef]

98. Chen, M.L.; He, Y.J.; Chen, X.W.; Wang, J.H. Quantum Dots Conjugated with $\mathrm{Fe}_{3} \mathrm{O}_{4}$-Filled Carbon Nanotubes for Cancer-Targeted Imaging and Magnetically Guided Drug Delivery. Langmuir 2012, 28, 16469-16476. [CrossRef] [PubMed]

99. Wu, Y.; Wei, Y.; Wang, J.P.; Jiang, K.L.; Fan, S.S. Conformal $\mathrm{Fe}_{3} \mathrm{O}_{4}$ Sheath on Aligned Carbon Nanotube Scaffolds as High-Performance Anodes for Lithium Ion Batteries. Nano Lett. 2013, 13, 818-823. [CrossRef] [PubMed]

100. Zheng, L.; Hu, L.; Yang, F.; Guo, T. Improvement of the field emission properties of carbon nanotubes by CNT/Fe3O4composite electrophoretic deposition. J. Semicond. 2011, 32, 126001. [CrossRef] 
101. Guo, Q.X.; Guo, P.F.; Li, J.T.; Yin, H.; Liu, J.; Xiao, F.L.; Shen, D.X.; Li, N. $\mathrm{Fe}_{3} \mathrm{O}_{4}$-CNTs nanocomposites: Inorganic dispersant assisted, hydrothermal synthesis and application in lithium ion batteries. J. Solid State Chem. 2014, 213, 104-109. [CrossRef]

102. Zhu, L.Y.; Zeng, X.J.; Chen, M.; Yu, R.H. Controllable permittivity in $3 \mathrm{D} \mathrm{Fe}_{3} \mathrm{O}_{4} / \mathrm{CNTs}$ network for remarkable microwave absorption performances. RSC Adv. 2017, 7, 26801-26808. [CrossRef]

103. Zhang, X.J.; Hao, L.Y.; Wang, H.H.; Zhu, X.Q.; Zhang, Z.Y.; Hu, X.H.; Jiang, W. Preparation and Characterization of Superparamagnetic $\mathrm{Fe}_{3} \mathrm{O}_{4} / \mathrm{CNTs}$ Nanocomposites Dual-drug Carrier. J. Wuhan Univ. Technol. 2017, 32, 42-46. [CrossRef]

104. Alegret, N.; Criado, A.; Prato, M. Recent Advances of Graphene-based Hybrids with Magnetic Nanoparticles for Biomedical Applications. Curr. Med. Chem. 2017, 24, 529-536. [CrossRef] [PubMed]

105. Wei, W.; Yang, S.B.; Zhou, H.X.; Lieberwirth, I.; Feng, X.L.; Mullen, K. 3D Graphene Foams Cross-linked with Pre-encapsulated $\mathrm{Fe}_{3} \mathrm{O}_{4}$ Nanospheres for Enhanced Lithium Storage. Adv. Mater. 2013, 25, 2909-2914. [CrossRef] [PubMed]

106. Lv, X.S.; Xue, X.Q.; Jiang, G.M.; Wu, D.L.; Sheng, T.T.; Zhou, H.Y.; Xu, X.H. Nanoscale Zero-Valent Iron (nZVI) assembled on magnetic $\mathrm{Fe}_{3} \mathrm{O}_{4}$ /graphene for Chromium (VI) removal from aqueous solution. J. Colloid Interfaces Sci. 2014, 417, 51-59. [CrossRef] [PubMed]

107. Xie, G.Q.; Xi, P.X.; Liu, H.Y.; Chen, F.J.; Huang, L.; Shi, Y.J.; Hou, F.P.; Zeng, Z.Z.; Shao, C.W.; Wang, J. A facile chemical method to produce superparamagnetic graphene oxide- $\mathrm{Fe}_{3} \mathrm{O}_{4}$ hybrid composite and its application in the removal of dyes from aqueous solution. J. Mater. Chem. 2012, 22, 1033-1039. [CrossRef]

108. Zubir, N.A.; Yacou, C.; Motuzas, J.; Zhang, X.W.; Zhao, X.S.; da Costa, J.C.D. The sacrificial role of graphene oxide in stabilising a Fenton-like catalyst $\mathrm{GO}-\mathrm{Fe}_{3} \mathrm{O}_{4}$. Chem. Commun. 2015, 51, 9291-9293. [CrossRef] [PubMed]

109. Teymourian, H.; Salimi, A.; Khezrian, $\mathrm{S}$. $\mathrm{Fe}_{3} \mathrm{O}_{4}$ magnetic nanoparticles/reduced graphene oxide nanosheets as a novel electrochemical and bioeletrochemical sensing platform. Biosens. Bioelectron. 2013, 49, 1-8. [CrossRef] [PubMed]

110. Karthikeyan, K.; Kalpana, D.; Amaresh, S.; Lee, Y.S. Microwave synthesis of graphene/magnetite composite electrode material for symmetric supercapacitor with superior rate performance. RSC Adv. 2012, 2, 12322-12328. [CrossRef]

111. Hu, C.G.; Mou, Z.Y.; Lu, G.W.; Chen, N.; Dong, Z.L.; Hu, M.J.; Qu, L.T. 3D graphene-Fe ${ }_{3} \mathrm{O}_{4}$ nanocomposites with high-performance microwave absorption. Phys. Chem. Chem. Phys. 2013, 15, 13038-13043. [CrossRef] [PubMed]

112. Zhou, C.H.; Wu, H.; Wang, M.L.; Huang, C.S.; Yang, D.P.; Jia, N.Q. Functionalized graphene oxide $/ \mathrm{Fe}_{3} \mathrm{O}_{4}$ hybrids for cellular magnetic resonance imaging and fluorescence labeling. Mater. Sci. Eng. C-Mater. 2017, 78, 817-825. [CrossRef] [PubMed]

113. Kumar, R.; Singh, R.K.; Vaz, A.R.; Savu, R.; Moshkalev, S.A. Self-Assembled and One-Step Synthesis of Interconnected 3D Network of $\mathrm{Fe}_{3} \mathrm{O}_{4} /$ Reduced Graphene Oxide Nanosheets Hybrid for High-Performance Supercapacitor Electrode. ACS Appl. Mater. Int. 2017, 9, 8880-8890. [CrossRef] [PubMed]

114. Zhao, L.; Gao, M.M.; Yue, W.B.; Jiang, Y.; Wang, Y.; Ren, Y.; Hu, F.Q. Sandwich-Structured Graphene$\mathrm{Fe}_{3} \mathrm{O}_{4} @$ Carbon Nanocomposites for High-Performance Lithium-Ion Batteries. ACS Appl. Mater. Int. 2015, 7, 9709-9715. [CrossRef] [PubMed]

115. Xu, C.; Sun, S. New forms of superparamagnetic nanoparticles for biomedical applications. Adv. Drug Deliv. Rev. 2013, 65, 732-743. [CrossRef] [PubMed]

116. Chen, H.; Qi, F.; Zhou, H.; Jia, S.; Gao, Y.; Koh, K.; Yin, Y. $\mathrm{Fe}_{3} \mathrm{O}_{4} @ \mathrm{Au}$ nanoparticles as a means of signal enhancement in surface plasmon resonance spectroscopy for thrombin detection. Sens. Actuators B-Chem. 2015, 212, 505-511. [CrossRef]

117. Li, C.M.; Chen, T.; Ocsoy, I.; Zhu, G.Z.; Yasun, E.; You, M.X.; Wu, C.C.; Zheng, J.; Song, E.Q.; Huang, C.Z.; et al. Gold- Coated $\mathrm{Fe}_{3} \mathrm{O}_{4}$ Nanoroses with Five Unique Functions for Cancer Cell Targeting, Imaging, and Therapy. Adv. Funct. Mater. 2014, 24, 1772-1780. [CrossRef] [PubMed]

118. Mahmood, A.; Ramay, S.M.; Al-Zaghayer, Y.S.; AlHazaa, A.A.N.; Al Masary, W.A.; Atiq, S. Synthesis and investigation of photocatalytic properties of $\mathrm{Au} / \mathrm{Fe}_{3} \mathrm{O}_{4}$ nanocomposite materials for degradation of methylene blue. Desalin. Water Treat. 2016, 57, 20069-20075. [CrossRef] 
119. Li, J.C.; Hu, Y.; Yang, J.; Wei, P.; Sun, W.J.; Shen, M.W.; Zhang, G.X.; Shi, X.Y. Hyaluronic acid-modified $\mathrm{Fe}_{3} \mathrm{O}_{4} @ \mathrm{Au}$ core/shell nanostars for multimodal imaging and photothermal therapy of tumors. Biomaterials 2015, 38, 10-21. [CrossRef] [PubMed]

120. Silva, S.M.; Tavallaie, R.; Sandiford, L.; Tilley, R.D.; Gooding, J.J. Gold coated magnetic nanoparticles: From preparation to surface modification for analytical and biomedical applications. Chem. Commun. 2016, 52, 7528-7540. [CrossRef] [PubMed]

121. Sun, H.Y.; Jiao, X.L.; Han, Y.Y.; Jiang, Z.; Chen, D.R. Synthesis of $\mathrm{Fe}_{3} \mathrm{O}_{4}$-Au Nanocomposites with Enhanced Peroxidase-Like Activity. Eur. J. Inorg. Chem. 2013, 2013, 109-114. [CrossRef]

122. Ghorbani, M.; Hamishehkar, H.; Arsalani, N.; Entezami, A.A. Preparation of thermo and pH-responsive polymer@Au/Fe3O4 core/shell nanoparticles as a carrier for delivery of anticancer agent. J. Nanopart. Res. 2015, 17, 305. [CrossRef]

123. Lo, C.K.; Xiao, D.; Choi, M.M.F. Homocysteine-protected gold-coated magnetic nanoparticles: Synthesis and characterisation. J. Mater. Chem. 2007, 17, 2418. [CrossRef]

124. Yan, F.; Sun, R. Facile synthesis of bifunctional $\mathrm{Fe}_{3} \mathrm{O}_{4} / \mathrm{Au}$ nanocomposite and their application in catalytic reduction of 4-nitrophenol. Mater. Res. Bull. 2014, 57, 293-299. [CrossRef]

125. Jin, R.; Song, D.Q.; Xiong, H.X.; Ai, L.S.; Ma, P.Y.; Sun, Y. Magnetic core/shell $\mathrm{Fe}_{3} \mathrm{O}_{4} / \mathrm{Au}$ nanoparticles for studies of quinolones binding to protein by fluorescence spectroscopy. Luminescence 2016, 31, 499-506. [CrossRef] [PubMed]

126. Freitas, M.; Viswanathan, S.; Nouws, H.P.; Oliveira, M.B.; Delerue-Matos, C. Iron oxide/gold core/shell nanomagnetic probes and CdS biolabels for amplified electrochemical immunosensing of Salmonella typhimurium. Biosens. Bioelectron. 2014, 51, 195-200. [CrossRef] [PubMed]

127. Li, L.; Du, Y.M.; Mak, K.Y.; Leung, C.W.; Pong, P.W.T. Novel Hybrid Au/ $\mathrm{Fe}_{3} \mathrm{O}_{4}$ Magnetic Octahedron-like Nanoparticles with Tunable Size. IEEE Trans. Magn. 2014, 50, 1-5.

128. Salihov, S.V.; Ivanenkov, Y.A.; Krechetov, S.P.; Veselov, M.S.; Sviridenkova, N.V.; Savchenko, A.G.; Klyachko, N.L.; Golovin, Y.I.; Chufarova, N.V.; Beloglazkina, E.K.; et al. Recent advances in the synthesis of Fe3O4@AU core/shell nanoparticles. J. Magn. Magn. Mater. 2015, 394, 173-178. [CrossRef]

129. Wang, Z.J.; Wu, L.N.; Wang, F.P.; Jiang, Z.H.; Shen, B.Z. Durian-like multi-functional $\mathrm{Fe}_{3} \mathrm{O}_{4}$-Au nanoparticles: Synthesis, characterization and selective detection of benzidine. J. Mater. Chem. A 2013, 1, 9746-9751. [CrossRef]

130. Li, F.; Yu, Z.F.; Zhao, L.Y.; Xue, T. Synthesis and application of homogeneous Fe3O4 core/Au shell nanoparticles with strong SERS effect. RSC Adv. 2016, 6, 10352-10357. [CrossRef]

131. Hu, Y.; Meng, L.J.; Niu, L.Y.; Lu, Q.H. Facile Synthesis of Superparamagnetic $\mathrm{Fe}_{3} \mathrm{O}_{4} @$ polyphosphazene@Au Shells for Magnetic Resonance Imaging and Photothermal Therapy. ACS Appl. Mater. Int. 2013, 5, 4586-4591. [CrossRef] [PubMed]

132. Zhou, J.; Meng, L.; Lu, Q. Core@shell nanostructures for photothermal conversion: Tunable noble metal nanoshells on cross-linked polymer submicrospheres. J. Mater. Chem. 2010, 20, 5493. [CrossRef]

133. Ramos-Tejada, M.D.; Viota, J.L.; Rudzka, K.; Delgado, A.V. Preparation of multi-functionalized $\mathrm{Fe}_{3} \mathrm{O}_{4} / \mathrm{Au}$ nanoparticles for medical purposes. Colloid Surf. B. 2015, 128, 1-7. [CrossRef] [PubMed]

134. Du, J.J.; Jing, C.Y. Preparation of Thiol Modified $\mathrm{Fe}_{3} \mathrm{O}_{4} @ \mathrm{Ag}$ Magnetic SERS Probe for PAHs Detection and Identification. J. Phys. Chem. C 2011, 115, 17829-17835. [CrossRef]

135. Satvekar, R.K.; Tiwari, A.P.; Rohiwal, S.S.; Tiwale, B.M.; Pawar, S.H. A DNA-Assembled $\mathrm{Fe}_{3} \mathrm{O}_{4} @ \mathrm{Ag} \mathrm{Nanorod}$ in Silica Matrix for Cholesterol Biosensing. J. Mater. Eng. Perform. 2015, 24, 4691-4695. [CrossRef]

136. Chen, J.Z.; Liu, Y.J.; Zhu, G.X.; Yuan, A.H. Ag@ $@ \mathrm{Fe}_{3} \mathrm{O}_{4}$ nanowire: Fabrication, characterization and peroxidase-like activity. Cryst. Res. Technol. 2014, 49, 309-314. [CrossRef]

137. Gao, G.; Wang, K.; Huang, P.; Zhang, Y.X.; Zhi, X.; Bao, C.C.; Cui, D.X. Superparamagnetic $\mathrm{Fe}_{3} \mathrm{O}_{4}-\mathrm{Ag}_{\mathrm{g}}$ hybrid nanocrystals as a potential contrast agent for CT imaging. Crystengcomm 2012, 14, 7556-7559. [CrossRef]

138. Du, J.J.; Cui, J.L.; Jing, C.Y. Rapid in situ identification of arsenic species using a portable $\mathrm{Fe}_{3} \mathrm{O}_{4} @ \mathrm{Ag} \mathrm{SERS}$ sensor. Chem. Commun. 2014, 50, 347-349. [CrossRef] [PubMed]

139. Harifi, T.; Montazer, M. Photo-, Bio-, and Magneto-active Colored Polyester Fabric with Hydrophobic/ Hydrophilic and Enhanced Mechanical Properties through Synthesis of $\mathrm{TiO}_{2} / \mathrm{Fe}_{3} \mathrm{O}_{4} / \mathrm{Ag}$ Nanocomposite. Ind. Eng. Chem. Res. 2014, 53, 1119-1129. [CrossRef] 
140. Xiong, R.; Lu, C.H.; Wang, Y.R.; Zhou, Z.H.; Zhang, X.X. Nanofibrillated cellulose as the support and reductant for the facile synthesis of $\mathrm{Fe}_{3} \mathrm{O}_{4} / \mathrm{Ag}$ nanocomposites with catalytic and antibacterial activity. J. Mater. Chem. A 2013, 1, 14910-14918. [CrossRef]

141. Wang, L.Y.; Sun, Y.; Wang, J.; Wang, J.A.; Yu, A.M.; Zhang, H.Q.; Song, D.Q. Preparation of surface plasmon resonance biosensor based on magnetic core/shell $\mathrm{Fe}_{3} \mathrm{O}_{4} / \mathrm{SiO}_{2}$ and $\mathrm{Fe}_{3} \mathrm{O}_{4} / \mathrm{Ag} / \mathrm{SiO}_{2}$ nanoparticles. Colloid Surf. B 2011, 84, 484-490. [CrossRef] [PubMed]

142. Akhundi, A.; Habibi-Yangjeh, A. High performance magnetically recoverable g- $\mathrm{C}_{3} \mathrm{~N}_{4} / \mathrm{Fe}_{3} \mathrm{O}_{4} / \mathrm{Ag} / \mathrm{Ag} \mathrm{SO}_{3}$ plasmonic photocatalyst for enhanced photocatalytic degradation of water pollutants. Adv. Powder Technol. 2017, 28, 565-574. [CrossRef]

143. An, Q.; Zhang, P.; Li, J.M.; Ma, W.F.; Guo, J.; Hu, J.; Wang, C.C. Silver-coated magnetite-carbon core-shell microspheres as substrate-enhanced SERS probes for detection of trace persistent organic pollutants. Nanoscale 2012, 4, 5210-5216. [CrossRef] [PubMed]

144. Ye, Y.J.; Chen, J.; Ding, Q.Q.; Lin, D.Y.; Dong, R.L.; Yang, L.B.; Liu, J.H. Sea-urchin-like $\mathrm{Fe}_{3} \mathrm{O}_{4} @$ C@Ag particles: An efficient SERS substrate for detection of organic pollutants. Nanoscale 2013, 5, 5887-5895. [CrossRef] [PubMed]

145. Liang, H.X.; Niu, H.L.; Li, P.; Tao, Z.Y.; Mao, C.J.; Song, J.M.; Zhang, S.Y. Multifunctional Fe $\mathrm{O}_{4} @ C @$ Ag hybrid nanoparticles: Aqueous solution preparation, characterization and photocatalytic activity. Mater. Res. Bull. 2013, 48, 2415-2419. [CrossRef]

146. Xia, H.Q.; Cui, B.; Zhou, J.H.; Zhang, L.L.; Zhang, J.; Guo, X.H.; Guo, H.L. Synthesis and characterization of $\mathrm{Fe}_{3} \mathrm{O}_{4} @ \mathrm{C} @ \mathrm{Ag}$ nanocomposites and their antibacterial performance. Appl. Surf. Sci. 2011, 257, 9397-9402. [CrossRef]

147. Chen, J.; Guo, Z.; Wang, H.B.; Gong, M.; Kong, X.K.; Xia, P.; Chen, Q.W. Multifunctional Fe $\mathrm{O}_{4} @ C @ A g$ hybrid nanoparticles as dual modal imaging probes and near-infrared light-responsive drug delivery platform. Biomaterials 2013, 34, 571-581. [CrossRef] [PubMed]

148. Bisht, G.; Rayamajhi, S.; Biplab, K.C.; Paudel, S.N.; Karna, D.; Shrestha, B.G. Synthesis, Characterization,

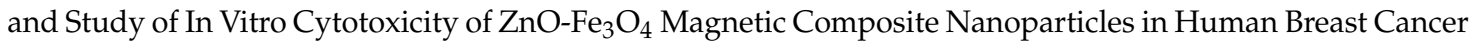
Cell Line (MDA-MB-231) and Mouse Fibroblast (NIH 3T3). Nanoscale Res. Lett. 2016, 11, 11. [CrossRef] [PubMed]

149. Saffari, J.; Mir, N.; Ghanbari, D.; Khandan-Barani, K.; Hassanabadi, A.; Hosseini-Tabatabaei, M.R. Sonochemical synthesis of $\mathrm{Fe}_{3} \mathrm{O}_{4} / \mathrm{ZnO}$ magnetic nanocomposites and their application in photo-catalytic degradation of various organic dyes. J. Mater. Sci-Mater. 2015, 26, 9591-9599. [CrossRef]

150. Wang, J.; Yang, J.; Li, X.; Wang, D.; Wei, B.; Song, H.; Li, X.; Fu, S. Preparation and photocatalytic properties of magnetically reusable $\mathrm{Fe}_{3} \mathrm{O}_{4} @ \mathrm{ZnO}$ core/shell nanoparticles. Phys. E 2016, 75, 66-71. [CrossRef]

151. Shekofteh-Gohari, M.; Habibi-Yangjeh, A. $\mathrm{Fe}_{3} \mathrm{O}_{4} / \mathrm{ZnO} / \mathrm{CoWO}$ nanocomposites: Novel magnetically separable visible-light-driven photocatalysts with enhanced activity in degradation of different dye pollutants. Ceram. Int. 2017, 43, 3063-3071. [CrossRef]

152. Chai, L.; Wang, Y.; Zhao, N.; Yang, W.; You, X. Sulfate-doped $\mathrm{Fe}_{3} \mathrm{O}_{4} / \mathrm{Al}_{2} \mathrm{O}_{3}$ nanoparticles as a novel adsorbent for fluoride removal from drinking water. Water Res. 2013, 47, 4040-4049. [CrossRef] [PubMed]

153. Tan, L.; Zhang, X.; Liu, Q.; Jing, X.; Liu, J.; Song, D.; Hu, S.; Liu, L.; Wang, J. Synthesis of $\mathrm{Fe}_{3} \mathrm{O}_{4} @ \mathrm{TiO}_{2}$ core-shell magnetic composites for highly efficient sorption of uranium (VI). Colloid Surf. A 2015, 469, 279-286. [CrossRef]

154. Liu, J.; Xu, J.; Che, R.; Chen, H.; Liu, M.; Liu, Z. Hierarchical $\mathrm{Fe}_{3} \mathrm{O}_{4} @ \mathrm{TiO}_{2}$ yolk-shell microspheres with enhanced microwave-absorption properties. Chemistry 2013, 19, 6746-6752. [CrossRef] [PubMed]

155. Wu, W.; He, Q.; Jiang, C. Magnetic iron oxide nanoparticles: Synthesis and surface functionalization strategies. Nanoscale Res. Lett. 2008, 3, 397-415. [CrossRef] [PubMed]

156. Zeng, Q.; Jiang, D.; Yang, S. Enhancement of magnetic properties in hard/soft $\mathrm{CoFe}_{2} \mathrm{O}_{4} / \mathrm{Fe}_{3} \mathrm{O}_{4}$ nanocomposites. RSC Adv. 2016, 6, 46143-46148. [CrossRef]

157. Fei, C.; Zhang, Y.; Yang, Z.; Liu, Y.; Xiong, R.; Shi, J.; Ruan, X. Synthesis and magnetic properties of hard magnetic $\left(\mathrm{CoFe}_{2} \mathrm{O}_{4}\right)$-soft magnetic $\left(\mathrm{Fe}_{3} \mathrm{O}_{4}\right)$ nano-composite ceramics by SPS technology. J. Magn. Magn. Mater. 2011, 323, 1811-1816. [CrossRef]

158. Lavorato, G.; Winkler, E.; Rivas-Murias, B.; Rivadulla, F. Thickness dependence of exchange coupling in epitaxialFe $\mathrm{O}_{4} / \mathrm{CoFe}_{2} \mathrm{O}_{4}$ soft/hard magnetic bilayers. Phys. Rev. B. 2016, 94, 054405. [CrossRef] 
159. Yi, F. Magnetic properties of hard $\left(\mathrm{CoFe}_{2} \mathrm{O}_{4}\right)$-soft $\left(\mathrm{Fe}_{3} \mathrm{O}_{4}\right)$ composite ceramics. Ceram. Int. 2014, 40, 7837-7840. [CrossRef]

160. Shaterabadi, Z.; Nabiyouni, G.; Soleymani, M. High impact of in situ dextran coating on biocompatibility, stability and magnetic properties of iron oxide nanoparticles. Mat. Sci. Eng. C-Mater. 2017, 75, 947-956. [CrossRef] [PubMed]

161. Osborne, E.A.; Atkins, T.M.; Gilbert, D.A.; Kauzlarich, S.M.; Liu, K.; Louie, A.Y. Rapid microwave-assisted synthesis of dextran-coated iron oxide nanoparticles for magnetic resonance imaging. Nanotechnology 2012, 23, 215602. [CrossRef] [PubMed]

162. Shete, P.B.; Patil, R.M.; Thorat, N.D.; Prasad, A.; Ningthoujam, R.S.; Ghosh, S.J.; Pawar, S.H. Magnetic chitosan nanocomposite for hyperthermia therapy application: Preparation, characterization and in vitro experiments. Appl. Surf. Sci. 2014, 288, 149-157. [CrossRef]

163. Mohammadi, A.; Daemi, H.; Barikani, M. Fast removal of malachite green dye using novel superparamagnetic sodium alginate-coated $\mathrm{Fe}_{3} \mathrm{O}_{4}$ nanoparticles. Int. J. Biol. Macromol. 2014, 69, 447-455. [CrossRef] [PubMed]

164. Anbarasu, M.; Anandan, M.; Chinnasamy, E.; Gopinath, V.; Balamurugan, K. Synthesis and characterization of polyethylene glycol (PEG) coated $\mathrm{Fe}_{3} \mathrm{O}_{4}$ nanoparticles by chemical co-precipitation method for biomedical applications. Spectrochim. Acta A 2015, 135, 536-539. [CrossRef] [PubMed]

165. Ardiyanti, H.; Suharyadi, E.; Kato, T.; Iwata, S. Crystal structures and magnetic properties of magnetite $\left(\mathrm{Fe}_{3} \mathrm{O}_{4}\right)$ / polyvinyl alcohol (PVA) ribbon. AIP Conf. Proc. 2016, 1725, 020007.

166. Ma, Y.R.; Zhang, X.L.; Zeng, T.; Cao, D.; Zhou, Z.; Li, W.H.; Niu, H.Y.; Cai, Y.Q. Polydopamine-Coated Magnetic Nanoparticles for Enrichment and Direct Detection of Small Molecule Pollutants Coupled with MALDI-TOF-MS. ACS Appl. Mater. Int. 2013, 5, 1024-1030. [CrossRef] [PubMed]

167. Karimzadeh, I.; Aghazadeh, M.; Ganjali, M.R.; Norouzi, P.; Doroudi, T.; Kolivand, P.H. Saccharide-coated superparamagnetic $\mathrm{Fe}_{3} \mathrm{O}_{4}$ nanoparticles (SPIONs) for biomedical applications: An efficient and scalable route for preparation and in situ surface coating through cathodic electrochemical deposition (CED). Mater. Lett. 2017, 189, 290-294. [CrossRef]

168. Calatayud, M.P.; Riggio, C.; Raffa, V.; Sanz, B.; Torres, T.E.; Ibarra, M.R.; Hoskins, C.; Cuschieri, A.; Wang, L.; Pinkernelle, J.; Keilhofff, G.; Goya, G.F. Neuronal cells loaded with PEI-coated $\mathrm{Fe}_{3} \mathrm{O}_{4}$ nanoparticles for magnetically guided nerve regeneration. J. Mater. Chem. B 2013, 1, 3607-3616. [CrossRef]

169. Rose, P.A.; Praseetha, P.K.; Bhagat, M.; Alexander, P.; Abdeen, S.; Chavali, M. Drug Embedded PVP Coated Magnetic Nanoparticles for Targeted Killing of Breast Cancer Cells. Technol. Cancer Res. 2013, 12, 463-472. [CrossRef] [PubMed]

170. Yang, G.; Zhang, B.L.; Wang, J.; Wang, M.; Xie, S.B.; Li, X. Synthesis and characterization of poly(lactic acid)-modified superparamagnetic iron oxide nanoparticles. J. Sol-Gel Sci. Technol. 2016, 77, 335-341. [CrossRef]

171. Liu, R.; Guo, Y.L.; Odusote, G.; Qu, F.L.; Priestley, R.D. Core-Shell $\mathrm{Fe}_{3} \mathrm{O}_{4}$ Polydopamine Nanoparticles Serve Multipurpose as Drug Carrier, Catalyst Support and Carbon Adsorbent. ACS Appl. Mater. Int. 2013, 5, 9167-9171. [CrossRef] [PubMed]

172. Hauser, A.K.; Mathias, R.; Anderson, K.W.; Hilt, J.Z. The effects of synthesis method on the physical and chemical properties of dextran coated iron oxide nanoparticles. Mater. Chem. Phys. 2015, 160, 177-186. [CrossRef] [PubMed]

173. Fu, C.P.; Zhou, H.P.; Wang, Y.N.; Liu, D.; Li, J.M.; Deng, H.J.; Qi, X.L.; Chen, T.; Zhang, L.M.; Li, G.X. One-pot synthesis of dextran-coated iron oxide nanoclusters for real-time regional lymph node mapping. Int. J. Nanomed. 2017, 12, 3365-3374. [CrossRef] [PubMed]

174. Unterweger, H.; Tietze, R.; Janko, C.; Zaloga, J.; Lyer, S.; Durr, S.; Taccardi, N.; Goudouri, O.M.; Hoppe, A.; Eberbeck, D.; et al. Development and characterization of magnetic iron oxide nanoparticles with a cisplatinbearing polymer coating for targeted drug delivery. Int. J. Nanomed. 2014, 9, 3659-3676. [CrossRef] [PubMed]

175. Mukhopadhyay, A.; Joshi, N.; Chattopadhyay, K.; De, G. A Facile Synthesis of PEG-Coated Magnetite $\left(\mathrm{Fe}_{3} \mathrm{O}_{4}\right)$ Nanoparticles and Their Prevention of the Reduction of Cytochrome C. ACS Appl. Mater. Int. 2012, 4, 142-149. [CrossRef] [PubMed]

176. Yu, M.; Huang, S.; Yu, K.J.; Clyne, A.M. Dextran and Polymer Polyethylene Glycol (PEG) Coating Reduce Both 5 and $30 \mathrm{~nm}$ Iron Oxide Nanoparticle Cytotoxicity in 2D and 3D Cell Culture. Int. J. Mol. Sci. 2012, 13, 5554-5570. [CrossRef] [PubMed] 
177. Thapa, B.; Diaz-Diestra, D.; Beltran-Huarac, J.; Weiner, B.R.; Morell, G. Enhanced MRI T-2 Relaxivity in Contrast-Probed Anchor-Free PEGylated Iron Oxide Nanoparticles. Nanoscale Res. Lett. 2017, 12, 13. [CrossRef] [PubMed]

178. Liu, D.F.; Wu, W.; Ling, J.J.; Wen, S.; Gu, N.; Zhang, X.Z. Effective PEGylation of Iron Oxide Nanoparticles for High Performance In Vivo Cancer Imaging. Adv. Funct. Mater. 2011, 21, 1498-1504. [CrossRef]

179. Lee, H.; Lee, E.; Kim, D.K.; Jang, N.K.; Jeong, Y.Y.; Jon, S. Antibiofouling Polymer-Coated Superparamagnetic Iron Oxide Nanoparticles as Potential Magnetic Resonance Contrast Agents for in Vivo Cancer Imaging. J. Am. Chem. Soc. 2006, 128, 7383-7389. [CrossRef] [PubMed]

180. Zhang, B.L.; Tu, Z.J.; Zhao, F.Y.; Wang, J. Superparamagnetic iron oxide nanoparticles prepared by using an improved polyol method. Appl. Surf. Sci. 2013, 266, 375-379. [CrossRef]

181. Honary, S.; Ebrahimi, P.; Rad, H.A.; Asgari, M. Optimization of preparation of chitosan-coated iron oxide nanoparticles for biomedical applications by chemometrics approaches. Int. Nano Lett. 2013, 3, 48-52. [CrossRef]

182. Tang, S.S.; Du, Q.J.; Liu, T.L.; Tan, L.F.; Niu, M.; Gao, L.; Huang, Z.B.; Fu, C.H.; Ma, T.C.; Meng, X.W.; et al. In Vivo Magnetic Resonance Imaging and Microwave Thermotherapy of Cancer Using Novel Chitosan Microcapsules. Nanoscale Res. Lett. 2016, 11, 334. [CrossRef] [PubMed]

183. Yan, H.; Yang, L.; Yang, Z.; Yang, H.; Li, A.; Cheng, R. Preparation of chitosan/poly(acrylic acid) magnetic composite microspheres and applications in the removal of copper(II) ions from aqueous solutions. J. Hazard. Mater. 2012, 229-230, 371-380. [CrossRef] [PubMed]

184. Qu, J.B.; Shao, H.H.; Jing, G.L.; Huang, F. PEG-chitosan-coated iron oxide nanoparticles with high saturated magnetization as carriers of 10-hydroxycamptothecin: Preparation, characterization and cytotoxicity studies. Colloid Surf. B. 2013, 102, 37-44. [CrossRef] [PubMed]

185. Zinadini, S.; Zinatizadeh, A.A.; Rahimi, M.; Vatanpour, V.; Zangeneh, H.; Beygzadeh, M. Novel high flux antifouling nanofiltration membranes for dye removal containing carboxymethyl chitosan coated $\mathrm{Fe}_{3} \mathrm{O}_{4}$ nanoparticles. Desalination 2014, 349, 145-154. [CrossRef]

186. Lin, M.F.; Thakur, V.K.; Tan, E.J.; Lee, P.S. Surface functionalization of $\mathrm{BaTiO}_{3}$ nanoparticles and improved electrical properties of $\mathrm{BaTiO}_{3}$ / polyvinylidene fluoride composite. RSC Adv. 2011, 1, 576-578. [CrossRef]

187. Thakur, V.K.; Lin, M.F.; Tan, E.J.; Lee, P.S. Green aqueous modification of fluoropolymers for energy storage applications. J. Mater. Chem. 2012, 22, 5951-5959. [CrossRef]

188. Thakur, V.K.; Yan, J.; Lin, M.F.; Zhi, C.Y.; Golberg, D.; Bando, Y.; Sim, R.; Lee, P.S. Novel polymer nanocomposites from bioinspired green aqueous functionalization of BNNTs. Polym. Chem. 2012, 3, 962-969. [CrossRef]

189. Cai, H.D.; An, X.; Cui, J.; Li, J.C.; Wen, S.H.; Li, K.G.; Shen, M.W.; Zheng, L.F.; Zhang, G.X.; Shi, X.Y. Facile Hydrothermal Synthesis and Surface Functionalization of Polyethyleneimine-Coated Iron Oxide Nanoparticles for Biomedical Applications. ACS Appl. Mater. Int. 2013, 5, 1722-1731. [CrossRef] [PubMed]

190. Bian, S.W.; Liu, S.; Chang, L. Synthesis of magnetically recyclable $\mathrm{Fe}_{3} \mathrm{O}_{4} @$ polydopamine-Pt composites and their application in hydrogenation reactions. J. Mater. Sci. 2016, 51, 3643-3649. [CrossRef]

191. Gopal, S.V.; Mini, R.; Jothy, V.B.; Joe, I.H. Synthesis and characterization of iron oxide nanoparticles using DMSO as a stabilizer. Mater. Today Proc. 2015, 2, 1051-1055. [CrossRef]

192. Wang, G.S.; Ma, Y.Y.; Tong, Y.; Dong, X.F. Synthesis, characterization and magnetorheological study of 3-aminopropyltriethoxysilane-modified $\mathrm{Fe}_{3} \mathrm{O}_{4}$ nanoparticles. Smart Mater. Struct. 2016, 25, 035028. [CrossRef]

193. Li, K.G.; Shen, M.W.; Zheng, L.F.; Zhao, J.L.; Quan, Q.M.; Shi, X.Y.; Zhang, G.X. Magnetic resonance imaging of glioma with novel APTS-coated superparamagnetic iron oxide nanoparticles. Nanoscale Res. Lett. 2014, 9 , 1-11. [CrossRef] [PubMed]

194. Mahmoud, M.E.; Amira, M.F.; Zaghloul, A.A.; Ibrahim, G.A.A. Microwave-enforced sorption of heavy metals from aqueous solutions on the surface of magnetic iron oxide-functionalized-3-aminopropyltriethoxysilane. Chem. Eng. J. 2016, 293, 200-206. [CrossRef]

195. Li, D.; Jiang, D.; Chen, M.; Xie, J.; Wu, Y.; Dang, S.; Zhang, J. An easy fabrication of monodisperse oleic acid-coated $\mathrm{Fe}_{3} \mathrm{O}_{4}$ nanoparticles. Mater. Lett. 2010, 64, 2462-2464. [CrossRef]

196. Yang, K.; Peng, H.; Wen, Y.; Li, N. Re-examination of characteristic FTIR spectrum of secondary layer in bilayer oleic acid-coated $\mathrm{Fe}_{3} \mathrm{O}_{4}$ nanoparticles. Appl. Surf. Sci. 2010, 256, 3093-3097. [CrossRef] 
197. Shete, P.B.; Patil, R.M.; Tiwale, B.M.; Pawar, S.H. Water dispersible oleic acid-coated $\mathrm{Fe}_{3} \mathrm{O}_{4}$ nanoparticles for biomedical applications. J. Magn. Magn. Mater. 2015, 377, 406-410. [CrossRef]

198. Marinca, T.F.; Chicinas, H.F.; Neamtu, B.V.; Isnard, O.; Pascuta, P.; Lupu, N.; Stoian, G.; Chicinas, I. Mechanosynthesis, structural, thermal and magnetic characteristics of oleic acid coated $\mathrm{Fe}_{3} \mathrm{O}_{4}$ nanoparticles. Mater. Chem. Phys. 2016, 171, 336-345. [CrossRef]

199. Velusamy, P.; Chia-Hung, S.; Shritama, A.; Kumar, G.V.; Jeyanthi, V.; Pandian, K. Synthesis of oleic acid coated iron oxide nanoparticles and its role in anti-biofilm activity against clinical isolates of bacterial pathogens. J. Taiwan Inst. Chem. E 2016, 59, 450-456. [CrossRef]

200. Jin, Y.J.; Liu, F.; Shan, C.; Tong, M.P.; Hou, Y.L. Efficient bacterial capture with amino acid modified magnetic nanoparticles. Water Res. 2014, 50, 124-134. [CrossRef] [PubMed]

201. Lin, J.F.; Tsai, C.C.; Lee, M.Z. Linear birefringence and dichroism in citric acid coated $\mathrm{Fe}_{3} \mathrm{O}_{4}$ magnetic nanoparticles. J. Magn. Magn. Mater. 2014, 372, 147-158. [CrossRef]

202. Mohapatra, S.; Mallick, S.K.; Maiti, T.K.; Ghosh, S.K.; Pramanik, P. Synthesis of highly stable folic acid conjugated magnetite nanoparticles for targeting cancer cells. Nanotechnology 2007, 18, 385102. [CrossRef]

203. Sreeja, V.; Jayaprabha, K.N.; Joy, P.A. Water-dispersible ascorbic-acid-coated magnetite nanoparticles for contrast enhancement in MRI. Appl. Nanosci. 2014, 5, 435-441. [CrossRef]

204. Li, J.; Chen, C.; Zhao, Y.; Hu, J.; Shao, D.; Wang, X. Synthesis of water-dispersible $\mathrm{Fe}_{3} \mathrm{O}_{4} @ \beta$-cyclodextrin by plasma-induced grafting technique for pollutant treatment. Chem. Eng. J. 2013, 229, 296-303. [CrossRef]

205. Mumtaz, S.; Wang, S.; Hussain, S.Z.; Abdullah, M.; Huma, Z.; Iqbal, Z.; Creran, B.; Rotello, V.M.; Hussain, I. Dopamine coated $\mathrm{Fe}_{3} \mathrm{O}_{4}$ nanoparticles as enzyme mimics for the sensitive detection of bacteria. Chem. Commun. 2017, 53, 12306-12308. [CrossRef] [PubMed]

206. Wei, H.; Insin, N.; Lee, J.; Han, H.S.; Cordero, J.M.; Liu, W.H.; Bawendi, M.G. Compact Zwitterion-Coated Iron Oxide Nanoparticles for Biological Applications. Nano Lett. 2012, 12, 22-25. [CrossRef] [PubMed]

207. Mamani, J.B.; Costa-Filho, A.J.; Cornejo, D.R.; Vieira, E.D.; Gamarra, L.F. Synthesis and characterization of magnetite nanoparticles coated with lauric acid. Mater. Charact. 2013, 81, 28-36. [CrossRef]

208. Ruiz, A.; Morais, P.C.; de Azevedo, R.B.; Lacava, Z.G.M.; Villanueva, A.; del Puerto Morales, M. Magnetic nanoparticles coated with dimercaptosuccinic acid: Development, characterization, and application in biomedicine. J. Nanopart. Res. 2014, 16. [CrossRef]

209. Liu, Y.X.; Wang, J.K. Effects of DMSA-Coated $\mathrm{Fe}_{3} \mathrm{O}_{4}$ Nanoparticles on the Transcription of Genes Related to Iron and Osmosis Homeostasis. Toxicol. Sci. 2013, 131, 521-536. [CrossRef] [PubMed]

210. Karimzadeh, I.; Aghazadeh, M.; Doroudi, T.; Ganjali, M.R.; Koliv, P.H.; Gharailou, D. Amino Acid Coated Superparamagnetic Iron Oxide Nanoparticles for Biomedical Applications Through a Novel Efficient Preparation Method. J. Clust. Sci. 2017, 28, 1259-1271. [CrossRef]

211. Sahoo, Y.; Goodarzi, A.; Swihart, M.T.; Ohulchanskyy, Y.T.; Kaur, N.; Furlani, E.P.; Prasad, P.N. Aqueous Ferrofluid of Magnetite Nanoparticles: Fluorescence Labeling and Magnetophoretic Control. J. Phys. Chem. B. 2005, 109, 3879-3885. [CrossRef] [PubMed]

212. Durdureanu-Angheluta, A.; Mihesan, C.; Doroftei, F.; Dascalu, A.; Ursu, L.; Velegrakis, M.; Pinteala, M. Formation by laser ablation in liquid (LAL) and characterization of citric acid-coated iron oxide nanoparticles. Rev. Roum. Chim. 2014, 59, 151-159.

213. An, P.; Zuo, F.; Wu, Y.P.; Zhang, J.H.; Zheng, Z.H.; Ding, X.B.; Peng, Y.X. Fast synthesis of dopamine-coated $\mathrm{Fe}_{3} \mathrm{O}_{4}$ nanoparticles through ligand-exchange method. Chin. Chem. Lett. 2012, 23, 1099-1102. [CrossRef]

214. Herranz, F.; Morales, M.P.; Roca, A.G.; Desco, M.; Ruiz-Cabello, J. A new method for the rapid synthesis of water stable superparamagnetic nanoparticles. Chemistry 2008, 14, 9126-9130. [CrossRef] [PubMed]

215. Patil, R.M.; Shete, P.B.; Thorat, N.D.; Otari, S.V.; Barick, K.C.; Prasad, A.; Ningthoujam, R.S.; Tiwale, B.M.; Pawar, S.H. Non-aqueous to aqueous phase transfer of oleic acid coated iron oxide nanoparticles for hyperthermia application. RSC Adv. 2014, 4, 4515-4522. [CrossRef]

216. Cai, J.; Miao, Y.Q.; Yu, B.Z.; Ma, P.; Li, L.; Fan, H.M. Large-Scale, Facile Transfer of Oleic Acid-Stabilized Iron Oxide Nanoparticles to the Aqueous Phase for Biological Applications. Langmuir 2017, 33, 1662-1669. [CrossRef] [PubMed] 
217. Pileni, M.P. Reverse Micelles as Microreactors. J. Phys. Chem. 1993, 97, 6961-6973. [CrossRef]

218. Yu, P.; Zhang, F.L.; Li, Z.Y.; Zhong, Z.Q.; Govorov, A.; Fu, L.; Tan, H.; Jagadish, C.; Wang, Z.M. Giant optical pathlength enhancement in plasmonic thin film solar cells using core-shell nanoparticles. J. Phys. D Appl. Phys. 2018, 51, 8. [CrossRef] 